\title{
Well-trodden highways and roads less traveled: Entrepreneurial-oriented behavior and identity construction in international entrepreneurship narratives
}

\section{Las sendas más trotadas y las rutas menos exploradas: Comportamiento emprendedor y construcción de identidad en base a narraciones sobre emprendimiento internacional}

\author{
Satu Korhonen ${ }^{1}$ (D) $\cdot$ Tanja Leppäaho ${ }^{1}$
}

Published online: 8 June 2019

(C) The Author(s) 2019

\begin{abstract}
We investigated the sense-making and contextual identity constructions of founderCEOs of early and rapidly internationalized new ventures, seeking to gain new insights into individual-level international entrepreneurship and international entrepreneurial behavior. Via a constructivist study of 19 founder-CEOs' life narratives, we explored how the formation of mental constructions - the narrative scripts - of the "self" as an actor derived from the founders' episodic autobiographical memories, and formed the basis for their international entrepreneurial behavior. We arrived at five scripts of international entrepreneurial behavior, i.e., a Pioneer, Native, Diplomat, Gambler, and an Eclectic. Our findings show (a) how meaning-loaded narratives emerge from the individual-level sense-making of temporal and contextual experiences and (b) how narratives feed into identity construction. They also show that individuals within IE have very different background scripts in the progression to where they are now.
\end{abstract}

Satu Korhonen

satu.korhonen@lut.fi

Tanja Leppäaho

tanja.leppaaho@lut.fi

1 School of Business and Management, Lappeenranta-Lahti University of Technology LUT, P.O. Box 20, 53851 Lappeenranta, Finland 


\section{Resumen}

En este trabajo, se investiga la creación de sentido y la construcción de identidad contextual por parte de fundadores-gerentes de nuevas empresas de temprana y rápida internacionalización con el objetivo de arrojar nueva luz sobre el emprendimiento internacional a nivel individual y el comportamiento emprendedor internacional. Mediante la elaboración de un estudio de corte constructivista, basado fundamentalmente en las narraciones de vida de 19 fundadores-gerentes, exploramos como la formación de construcciones mentales - los textos narrativos- del "yo" como un actor relevante pueden derivarse de las memorias autobiográficas y episódicas de los propios fundadores, configurando asimismo la base para entender su comportamiento emprendedor internacional. Se identifica, pues, de esta forma hasta un total de cinco descripciones (con)textuales distintas del comportamiento emprendedor internacional, a saber, la del Pionero, el Nativo, el Diplomático, el Jugador y el Ecléctico. Más concretamente, nuestros resultados muestran: (i) como las narraciones cargadas de significado emergen de la creación de sentido a nivel individual a partir de numerosas experiencias temporales y contextuales, y (ii) como dichas narraciones alimentan asimismo la construcción de identidad de cada emprendedor. También se pone igualmente de manifiesto como los emprendedores internacionales presentan, a nivel individual, textos sumamente diferentes sobre sus antecedentes vitales y en lo que concierne a su progresión hasta lo que son hoy en día.

Keywords International entrepreneur - International entrepreneurial behavior - Life experience $\cdot$ Narrative identity $\cdot$ Script

Palabras clave Emprendedor internacional - Comportamiento emprendedor internacional - Experiencia de vida $\cdot$ Identidad narrativa $\cdot$ Texto

\section{Summary highlights}

Contributions: Our study adds to the growing body of literature on individual-level international entrepreneurial behavior and brings insights to how founder-CEOs' life experiences and sense-making of them narrate the foundation - the script-for their socially constructed identities and (subsequent) behavior relative to their international venturing.

Research questions/purpose: Our study examines how founder-CEOs of early and rapidly internationalized new ventures make sense of their life experiences and construct their identities relative to their behavior as international entrepreneurs.

Basic methodology and information: This study employs a qualitative methodology as the most appropriate means for studying under-researched processes, such as the socially constructed view of the international entrepreneur, and is based on the openended life-narrative interviews conducted with 19 founder-CEOs of early and rapidly internationalized new ventures.

Results/findings: Our findings show how individuals, engaging in the narration of their journeys of becoming and being international entrepreneurs, construct their narrative 
identities as "scripts" — a Pioneer, Native, Diplomat, Gambler, and an Eclectic scriptfor their international entrepreneurial behavior. Findings of the life narratives illuminate how founder-CEOs' developmental experiences feed into and frame their international entrepreneurial behavior as emergent in the range of historically bound and generational contexts. Furthermore, our findings encompass the sense-making of international social interaction and the emotional aspects relative to one's international entrepreneurial journey.

Theoretical implications and recommendations: We contribute to the wider IE literature on the individual level. We provide with novel insights on how identities and international entrepreneurial behavior become manifested in different individuals, at different times, and through different contexts.

Practical implications and recommendations: The article highlights the importance of considering the various cultural and time contexts, generational contexts, and social contexts, as well as the emotional aspects in which one becomes and is an international entrepreneur. Such dimensions underpinning individuals' actions and behavior ought to be taken into consideration by entities contributing to the developmental processes of (potential) international entrepreneurs, such as education institutes as well as people in consultancy and media. The aim would hence be to develop reflective practices and reflexivity among those who engage in "writing the new scripts" of international entrepreneurship.

Limitations and future research suggestions: The nature of our interview data is subjective and socially constructed and relies on the individual's verbal output and ability to memorize past life events and experiences. Hence, being limited from an objective assessment of causal relationships of one's experience and behavior in and over time, we call for longitudinally unfolding research approaches and data generation. Our novel approach to international entrepreneurship at the individual level opens up interesting future directions for looking deeper into narrative scripts and their broader implications to their international venturing in different contexts; for example, comparisons between scripts, identity constructions, and behavior stemming from different cultural, institutional, political, or even industry settings would enable us to explore the assumptions and beliefs international entrepreneurs are embodying in their orientations towards international venturing.

\section{Introduction}

As noted by Oviatt and McDougall (2005b): 7), international entrepreneurship (IE) research seeks to understand "by whom and with what effects" international entrepreneurial opportunities are acted upon. Research on IE behavior (Oviatt and McDougall 2005a) has, on the whole, been dominated by firm-level studies (Joardar and Wu 2011; Jones et al. 2011). At the same time, early entrepreneurship scholars have remained close to the initial view of entrepreneurially oriented small firms as the extension of the individuals in charge (Lumpkin and Dess 1996). However, there have been relatively few explorations of the nature, motivation, or background of these international 
entrepreneurial actors (Autio 2005; Coviello 2015; Hannibal 2017; Jones and Casulli 2014; Jones et al. 2011; Keupp and Gassmann 2009; Peiris et al. 2012). Broadly speaking, in line with the definition of IE as an inherently entrepreneurial act, scholars agree that founders' initial perceptions, interpretations, knowledge, and know-how serve as the key influential factors in initial firm-level internationalization behavior (Oviatt and McDougall 2005a; Sarasvathy et al. 2014).

In conjunction with the lack of studies exploring the nature of IE entrepreneurs (Jones et al. 2011), one may well be curious as to the cognitive processes engaged in by international entrepreneurs (Jones and Casulli 2014; Reuber et al. 2018). Furthermore, in the constructivist stream of research, entrepreneurship is approached more as a "becoming" process (van Burg and Romme 2014; Steyaert and Katz 2004; Steyaert 1997). In such a process, the entrepreneurial actions of the founders are influenced by their prior developmental experiences and cognitive structures (Krueger 2007), more specifically, by how they interpret their life events and construct a sense of self (Morris et al. 2012) over time. In this paper, we seek to fill the gap by looking at IE individual behaviors (actions in the stream of events), operating in such a way as to construct identities and life narratives.

With these considerations in view, we undertook a constructivist exploration of the developmental foundations of (international) entrepreneurial behavior (Krueger 2007). In so doing, we sought to re-engage with real-life perspectives (Delios 2017) on "becoming" an international entrepreneur (Coviello 2015; Jones and Casulli 2014; Keupp and Gassmann 2009). Our research took the form of a qualitative study on the life narratives of the founder-CEOs of early and rapidly internationalized new ventures. Having conducted open-ended interviews with 19 founder-CEOs, we analyzed their experiences, considering how they made sense of the self as an actor relative to these experiences. This allowed us to see how their narrative identities unfolded as "scripts" of their IE behavior. In our findings, we present a pool of narratives, elaborating five exemplary scripts - a Pioneer, Native, Gambler, Diplomat, and an Eclectic. We suggest that these reflect differing individual-level constructions of "what it means to be an international entrepreneur" in the IE journey.

Our study contributes to IE literature on individual-level IE behavior (Coviello 2015; Jones et al. 2011; Prashantham et al. 2019; Sarasvathy et al. 2014) by exploring the developmental experiences and identity constructions of founders. Our findings illuminate life narratives to have emerged in a range of historically bound contexts (i.e., ideological, political, and cultural discussions within society) and generational contexts (i.e., multi-culturalism and digitalization), encompassing also experiences of international social interaction and emotional aspects. Moreover, in addressing the founders' sense-making processes and identity construction as the undercurrent for international entrepreneurial behavior (Coviello 2015; Hannibal 2017; Sarasvathy et al. 2014), we provide insights on how two "letter I" entities (International orientation and Identity) become manifested in different individuals, at different times, and through different contexts. According to our findings, international entrepreneurs construct identities and enact behaviors grounded in their sense-making of personal life experiences and in their interpretations of the various (temporal) contexts within which these experiences take place. As active participants in the streams of their contextual experiences (Morris et al. 2012), the temporal IE behaviors of international entrepreneurs 
emerge as grounded on their assumptions and understandings (Karp 2006). These in turn are derived from their cultural context (Pioneer script), generational context (Native script), and social context (Diplomat script), and from the emotions that underpin their actions and behavior (Gambler script).

The outline of the paper is as follows. We first provide an overview of the IE domain in terms of its main streams and less prevalent investigative approaches. The "Method" section covers our analytical approach to our qualitative data on founder-CEOs' life narratives, their selves, and their IE behavior. In the final sections, we discuss our findings and then indicate how our narrative inquiry may have theoretical and practical implications for IE processes at the individual level.

\section{Theoretical framework}

\section{Well-trodden highways: Entrepreneurial behavior and the founder profile in international entrepreneurship research}

In the IE field, entrepreneurship and internationalization are discussed as interdependent processes, with internationalization being viewed broadly as entrepreneurial behavior "manifested by events and outcomes in relation to time" (Jones and Coviello 2005: 299). Research on early internationalization, on the evolution of the cross-border activities of small firms, and on international entrepreneurial behavior (IE behavior) has mostly been conducted at the firm level (Coviello et al. 2011; Jones et al. 2011; McDougall-Covin et al. 2014). Moreover, the firms' characteristics (i.e., firm size and age), their behavior (i.e., internationalization patterns and pace), and the outcomes of such behavior (i.e., relative performance) have been investigated relative to the period of their inception or after the establishment of the firm (Coombs et al. 2009; Jones et al. 2011).

Fundamentally, research on entrepreneurial behavior has aimed to answer the question of what it means to be entrepreneurial (Miller 2011; Krueger 2007). Earlier studies tended to view "entrepreneurial" actions in terms of a particular personality, or else as the combined abilities of the entrepreneurial actor at the individual level (Schumpeter 1934), or in terms of the overall strategic orientation of the firm (Zahra et al. 2013). By contrast, current views of entrepreneurial behavior-seen, for example, in terms of an entrepreneurial orientation (EO) - tend to take into account firms' innovativeness, proactiveness, and risk-taking in relation to the environment and to decision-making (Miller 2011; Covin and Wales 2012), and, further, their need for autonomy (Lumpkin et al. 2009). Such attributes of the firm are theoretically and practically accepted as the key forces driving entrepreneurial activities and the overall abilities of firms to engage in entrepreneurial behavior (Covin and Wales 2012). This has been the point of departure for IE studies on the strategic orientations preceding successful outcomes in international new ventures (INVs) (Covin and Miller 2014; De Clercq et al. 2005; Jones and Coviello 2005; Knight and Liesch 2016).

Although IE scholars have for several years primarily focused on the strategic orientation of entrepreneurial firms, a number of scholars have continued to study entrepreneurial behavior as an individual phenomenon, with a specific focus on the 
behavior of important firm leaders, such as founders (Joardar and Wu 2011; Weaver et al. 2002). The tendency has been to treat individual founders as having a more or less fixed profile in terms of their entrepreneurial tendencies and attributes (Stewart et al. 1999). A combination of attributes is seen as driving the individual to engage in international new-entry activity (Covin and Miller 2014). Such studies are broadly in line with traditional theories of the entrepreneur (e.g., Kirzner 1997; Schumpeter 1934), such that international entrepreneurial actors - founders - are regarded as proactive and innovative risk-takers (Joardar and Wu 2011), persons who have initially developed a global vision and necessary competences (Oviatt and McDougall 1994; McDougall et al. 1994).

\section{A road less traveled: International entrepreneurs as the actors and sense-makers of their socially constructed identities}

In considering the IE phenomenon as a multi-dimensional process over time, scholars have moved towards an integrative notion of the founder as a sense-maker and of (international) entrepreneurship as a complex and dynamic phenomenon within a social context (Hannibal et al. 2016; Rasmussen et al. 2001; Sarasvathy et al. 2014). Consequently, instead of border-crossing behavior at founding being seen in terms of key individuals per se, there is increasing perception of founders as holistic bundles of identity, knowledge, and networks (Sarasvathy et al. 2014). In addition, studies on international entrepreneurs and their role in the behavioral processes of their firms have emphasized the life history of the founder (McGaughey 2007), the construction of identity (Coviello 2015), and related cognitive processes (Acedo and Jones 2007; Jones and Casulli 2014; Reuber et al. 2018). These are seen as relevant to IE behavior at both individual and firm levels.

\section{International entrepreneurial actors as sense-makers}

Entrepreneurs are socially and contextually embedded actors who, over time, gain a sense of agency in enacting their context (Baker and Welter 2018). Moreover, individual founders are active participants in the streams of their experiences (Morris et al. 2012), with their temporal performance - or behavior - being grounded on their personal assumptions, understandings, and emotions (Karp 2006). In other words, individuals' entrepreneurial actions are motivated by their underlying intentions and attitudes (Krueger 2007), whereas the mental orientations in venturing behavior are developed through and catalyzed by ongoing life experiences that the individuals make sense of (Sommer and Haug 2011; Krueger 2007). Such sense-making encompasses "the entrepreneur's attempt to construct meaning to his/her plans and ideas together with other actors" (Rasmussen et al. 2001: 80).

In discussing entrepreneurial behavior relative to internationalization, it is noteworthy that entry into international markets is inherently an entrepreneurial act. By virtue of the act, the founders of INVs have come to be perceived as persons with an initial international entrepreneurial orientation (Covin and Miller 2014). Such a view was already apparent at an early stage in IE research; thus, McDougall et al. (1994) argued that prior to founding, the founders - as key actors in the emerging IE phenomenon - had have over time become more alert to the possibilities for 
combining resources from different national markets, due to competencies developed through their earlier experiences. So far, there have been relatively few studies on how international entrepreneurs draw upon such prior experiences or cognitive insights (Butler et al. 2010; Jones and Casulli 2014; Rasmussen et al. 2001). However, some recent studies have emerged (e.g., Hannibal 2017; Lehto 2015) dealing more specifically with the founders' ongoing, subjective interpretations of past experiences and present activities, along with projections of future intentions.

\section{Life experiences and construction of identities enacting IE behavior}

Life experiences, especially in the early years of life, are central to individuals' cognitive structures (Gioia and Manz 1985), their sense of "self” and human agency (Bandura 2006), and their adaptation to social roles and behavior (McAdams 2013). Studies have been conducted on entrepreneurial cognition as a process (i.e., as the evolution of mental representations and constructs) (Grégoire et al. 2011) and on the development of cognitive structures as foundations for entrepreneurial behavior. Work in these fields has led to a greater understanding of how and why individuals perceive and enact the surrounding world of, e.g., entrepreneurial opportunities the way they do (Krueger 2007).

The processes of "becoming" an entrepreneur have started to receive more attention (Gartner 1988; Hytti 2005; Williams and Nadin 2013; Krueger 2007). Scholars have been encouraged to move from a purely static view of the founder profile and to pay more heed to founders' evolving identities (Nielsen and Lassen 2012). Accordingly, research on international entrepreneurs has begun to discuss how founders make sense of their contextual identities (Hannibal 2017), with consideration also of their intentions relative to their faith in their own entrepreneurial capabilities - i.e., their self-efficacy (Hannibal et al. 2016; Dehghanpour Farashah 2015).

In general, life experiences as narratives are seen as a fruitful source for describing human actions and experiences. The intrinsic interpretation of life experiences (Polkinghorne 1988) serves as the basic organizing principle of human cognition (Boland and Tenkasi 1995). Moreover, such life narratives give prominence to human agency (Riessman 1993). Thus, they are recognized as having a pre-eminent role in making sense of individuals' actions relative to the entrepreneurship phenomenon (Byrne and Shepherd 2015; Brown et al. 2008). As founders narrate (to themselves or others) their "entrepreneurial journeys" (McMullen and Dimov 2013), they make sense of a variety of experiences in a range of social contexts across time (Carsrud and Johnson 1989; Hisrich et al. 2007; Sarasvathy 2001; Shane et al. 2003), and, in so doing, form subjective meanings for their actions within complex entrepreneurial processes (Leitch and Harrison 2016; McMullen and Dimov 2013; Moroz and Hindle 2012; Selden and Fletcher 2015; Fayolle et al. 2016).

In line with the literature on the founder as a key sense-making actor in the IE process, we set out to explore the foundations of IE behavior from a constructivist perspective. This takes developmental experiences (Krueger 2007) and life narratives as the basis for identity and behavior (McAdams 2008). In our analytic work, we started by exploring founder-CEOs' construction of narrative identities (McAdams 2013) relative to the IE phenomenon. In other words, we looked at their underlying perceptions of themselves and at how they made sense of their international venturing behavior over time. 


\section{Method}

In this study, we employed a qualitative methodology. This appeared to be the most appropriate means for studying under-researched processes, such as the socially constructed view of IE and the developmental experiences in founder-CEOs' identity construction processes. Starting from an attempt to complement our view of IE with a sense-making perspective (Weick 1995; Rasmussen et al. 2001)-hence to include alternative interpretations of individual entrepreneurial behavior - we sought to apply our methods in such a way as to encompass the "fragile, emerging and provisional character of any kind of 'unit' that emerges from and is embedded within a process" (Steyaert 2007: 459). We also applied principles of narrative inquiry into human life experiences (Polkinghorne 1988; Riessman 1993), which see as having made major contributions to the study of human cognition, by drawing upon script theory and autobiographic memory (Hiles and Cermák 2008). Accordingly, we made use of life narratives as "scripts" (McAdams 2006). The scripts function as sense-making instruments (Brown et al. 2008) and, also, provide means for analyzing how research participants encode information about their experiences, the surrounding world (Labov 2013), and themselves (McAdams 2013).

\section{Data}

As part of a larger project in which we studied a range of processual paths to IE at the individual level, we conducted interviews with 19 founder-CEOs of small international ventures. These represented a variety of industries (see Table 1). Initially, with a view to having both "obtainable" and "important" data (Coviello and Jones 2004: 493), we selected the founder-CEOs through purposive sampling. The main criteria were (a) that they had founded a company that had been running for over two years; (b) that they had led the internationalization of the firm in some way or another during the first years of operation; (c) that they were managing the company at the time of the interview. Inevitably, all of the interviewed founder-CEOs shared a similar country context, i.e., the small open economy in Scandinavia. Since the distinction between small firms and entrepreneurial firms is a matter of emphasis (Coombs et al. 2009), and since many venture types are relevant in IE (Jones et al. 2011), we refrained from selecting the interviewees by any particular industry, strategy, or entry-mode characteristics (seeking thus to hear a maximally broad range of stories from the field). The founder-CEOs' firms had begun their international operations either (a) from inception or (b) within the first five years of operation. Operations were commenced either reactively, due to the firm's global client base and seemingly limited market in the country, or, proactively, due to the desire to seek new markets, challenges, and so on.

Generating narrative data Broadly speaking, a narrative refers to "the account of events in the world which are organized in a time-related sequence" (Watson 2009: 429). Narrative data, for their part, serve as means of accessing and providing a thick description of the contextually embedded sense-making of personally meaningful experience and knowledge (Birch and Miller 2000; Fletcher 2007; Johansson 2004; McMullen and Dimov 2013; Watson 2009). In inviting participants to talk about aspects of their life, researchers are, in effect, asking them to translate their "sense of 
self" into language (Birch and Miller 2000). The (transformative) sense-making cognitive activity pertaining to past, present, and future experiences (Weick 1995) both constitutes and is produced by narration. In this sense, the interviews themselves exist as opportunities for "(re)constructing narratives in different ways, evolving different

Table 1 Data

\begin{tabular}{|c|c|c|c|c|}
\hline Founder & Age & Main area of business & Education & $\begin{array}{l}\text { Year; duration } \\
\text { of interview }\end{array}$ \\
\hline Kim & $61-65$ & $\begin{array}{l}\text { Software design and development and } \\
\text { consulting services }\end{array}$ & $\begin{array}{l}\text { MSc in Economics and } \\
\text { further training in } \\
\text { exports }\end{array}$ & $\begin{array}{l}2015 ; 1 \mathrm{~h} \\
24 \mathrm{~m}\end{array}$ \\
\hline Per & $56-60$ & $\begin{array}{l}\text { Management consulting for industrial } \\
\text { companies }\end{array}$ & $\begin{array}{l}\text { BA in Engineering and } \\
\text { MBA }\end{array}$ & $\begin{array}{l}2015 ; 1 \mathrm{~h} \\
17 \mathrm{~m}\end{array}$ \\
\hline Mel & $31-35$ & $\begin{array}{l}\text { Software design and development and } \\
\text { consulting }\end{array}$ & $\begin{array}{l}\text { MSc in Economics and } \\
\text { some doctoral studies }\end{array}$ & $\begin{array}{l}2015 ; 1 \mathrm{~h} \\
21 \mathrm{~m}\end{array}$ \\
\hline Bert & $71-75$ & $\begin{array}{l}\text { Manufacturing of lifting and handling } \\
\text { machinery }\end{array}$ & Engineering degree & $\begin{array}{l}2017 ; 2 \mathrm{~h} \\
26 \mathrm{~m}\end{array}$ \\
\hline Cam & $46-50$ & $\begin{array}{l}\text { Internet-based tourism services, service } \\
\text { design, and consulting }\end{array}$ & $\begin{array}{l}\text { MSc in Business and } \\
\text { Economics }\end{array}$ & $\begin{array}{l}2017 ; 1 \mathrm{~h} \\
12 \mathrm{~m}\end{array}$ \\
\hline Moss & $26-30$ & Production of media, music, and film & $\mathrm{BA}$ in Media & $\begin{array}{l}2017 ; 1 \mathrm{~h} \\
51 \mathrm{~m}\end{array}$ \\
\hline $\mathrm{Oz}$ & $31-35$ & $\begin{array}{l}\text { Software design and development and } \\
\text { consulting services }\end{array}$ & BA in Natural Sciences & $2017 ; 2$ h 8 m \\
\hline Joe & $31-35$ & $\begin{array}{l}\text { Software design and development and } \\
\text { consulting services }\end{array}$ & $\mathrm{BA}$ in Engineering & $\begin{array}{l}2017 ; 1 \mathrm{~h} \\
33 \mathrm{~m}\end{array}$ \\
\hline Gio & $56-60$ & $\begin{array}{l}\text { Industrial machine and process development } \\
\text { services }\end{array}$ & $\mathrm{PhD}$ in Physics & $2017 ; 2$ h $6 \mathrm{~m}$ \\
\hline Ope & $45-50$ & $\begin{array}{l}\text { Production of communication technology and } \\
\text { attached services }\end{array}$ & $\begin{array}{l}\text { BA in Business } \\
\text { Administration }\end{array}$ & $\begin{array}{l}2017 ; 1 \mathrm{~h} \\
51 \mathrm{~m}\end{array}$ \\
\hline Hope & $36-40$ & Production of hygiene products & High school degree & $\begin{array}{l}2018 ; 1 \mathrm{~h} \\
37 \mathrm{~m}\end{array}$ \\
\hline Val & $56-60$ & $\begin{array}{l}\text { Production of communication technology, } \\
\text { software development, and attached } \\
\text { services }\end{array}$ & MSc in Engineering & $\begin{array}{l}2018 ; 2 \mathrm{~h} \\
00 \mathrm{~m}\end{array}$ \\
\hline Sam & $46-50$ & $\begin{array}{l}\text { Production of industrial measurement } \\
\text { technology and attached services }\end{array}$ & $\begin{array}{l}\text { MSc in Engineering and } \\
\text { some doctoral studies }\end{array}$ & $\begin{array}{l}2018 ; 1 \mathrm{~h} \\
49 \mathrm{~m}\end{array}$ \\
\hline Mack & $26-30$ & $\begin{array}{l}\text { Marketing agency and attached software } \\
\text { design and development }\end{array}$ & $\begin{array}{l}\text { BA in Business and } \\
\text { Economics }\end{array}$ & $\begin{array}{l}2017 ; 1 \mathrm{~h} \\
23 \mathrm{~m}\end{array}$ \\
\hline Stef & $41-45$ & $\begin{array}{l}\text { Production of measurement technology and } \\
\text { attached services }\end{array}$ & $\mathrm{PhD}$ in Physics & $\begin{array}{l}2018 ; 1 \mathrm{~h} \\
44 \mathrm{~m}\end{array}$ \\
\hline Lars & $71-75$ & Manufacturing of forest machinery & MSc in Engineering & $\begin{array}{l}2017 ; 1 \mathrm{~h} \\
27 \mathrm{~m}\end{array}$ \\
\hline Miles & $41-45$ & $\begin{array}{l}\text { Information tech. development and software } \\
\text { consultancy }\end{array}$ & $\begin{array}{l}\text { MSc in Business and } \\
\text { Economics }\end{array}$ & $2018 ; 50 \mathrm{~m}$ \\
\hline Sandy & $36-40$ & $\begin{array}{l}\text { R\&D and manufacturing of packaging for } \\
\text { cosmetics }\end{array}$ & $\mathrm{PhD}$ in Chemistry & $\begin{array}{l}2018 ; 1 \mathrm{~h} \\
15 \mathrm{~m}\end{array}$ \\
\hline Tim & $56-60$ & $\begin{array}{l}\text { Production of industrial measurement } \\
\text { technology }\end{array}$ & Electrical engineering & $\begin{array}{l}2017 ; 1 \mathrm{~h} \\
38 \mathrm{~m}\end{array}$ \\
\hline
\end{tabular}


perspectives on the past, leading to different understandings of the present, with implications for the future" (Birch and Miller 2000: 93; referring also to Ricoeur 1991; Rosenthal 1993). Overall, there is a well-theorized and thoroughly analyzed link between the construction of identity (Bruner 1995; Riessman 1993) and the mental representations of individuals structured in terms of narratives (Polkinghorne 1988). Of particular relevance for this study is the recognition of narrative as fundamental in the formation of entrepreneurial identity (Jones et al. 2008; Mills and Pawson 2006; Nielsen and Lassen 2012; Yitshaki and Kropp 2016).

To ensure that we received first-person, personal accounts of international entrepreneurs' experiences and sense-making regarding the early years of their progression to their present self, we generated data through open-ended narrative interviews (Riessman 1993). We, thus, used open-ended and elaborative questions to encourage the participants to discuss their experiences freely, obtaining rich accounts that encompassed early childhood, current activities, and future visions. By focusing on how the founder-CEOs had become international entrepreneurs, the thematic interview structure encouraged "story-telling" of personal life journeys. The interviewer's main task was to engage in attentive listening in follow of guidelines aiming at maximally non-directive and empathic interviewing, to take notes, and to encourage elaboration with content-specific questions. Broadly, the interview strategy can be summarized according to the simple principles laid out for biographical and narrative interviews (Rosenthal 1993; Hollway 1997; Hendry 2007), namely, the use of open-ended questions, with a willingness to elicit stories, to embrace silence, to avoid "why" questions, and to follow up using the interviewee's own ordering and phrasing.

In practice, the start of the interview entailed a single, open question forming a kind of invitation: "Please, tell me how you became an international entrepreneur." Beyond this, the interviews evolved on the basis of attentive listening and notetaking during the initial narration. This allowed the interviewer to follow up themes, following the narrated order, and using the respondent's own words and phrases. Such an approach led to further narration via open questioning. On-site recall of thematically relevant accounts activated the interviewee to elaborate events and experiences in greater detail. Simultaneously - in a constructivist manner-it engaged both the interviewee and the interviewer in sense-making and reconstruction (Rosenthal 1993). Each of the interviews was conducted on a one-on-one basis by the same interviewer. The interviews were audiotaped, with durations ranging from $50 \mathrm{~min}$ to $2 \mathrm{~h}$ and $26 \mathrm{~min}$. When transcribed, they produced 340 pages of text (Times New Roman, font 12, single space).

\section{Analyzing the narratives}

Over time, a person constructs plots for and internalizes experiences, covering events and the self within them as the evolving and integrative story of a life. The story is the script for the person's narrative identity construction (McAdams and McLean 2013). In this study, we aligned our approach with notions of human cognitive structures and mental representations of the surrounding world as modified by personally meaningful life experiences. Subsequent behavior is driven by the (now deeper) beliefs, adopted on the basis of the cognitive structures previously formed (Krueger 2007). Accordingly, in 
our analysis of the narratives (Polkinghorne 1988), we sought to follow the progressions through which founder-CEOs made sense of their early and ongoing experiences, forming a developing sense of their selves relative to their actions (McAdams 2013) within the stream of experiences relating to their IE journeys. Figure 1 encompasses the above-mentioned concepts. It also sets out our approach to narrative data, viewed as revealing scripts for the self and for behavior, used in the founder-CEOs' sense-making of their life experiences.

Our initial analysis resulted in a larger set of narrative episodes, providing an overall picture of the narratives constructed in our data (Lieblich et al. 1998), and the sensemaking of meaningful periods in the interviewees' lives. These narrative episodes were often referred to in the interviews and served as the "body" of the interviews. We also traced the experiences and life events that influenced the individual's personal internationalization orientation (not yet related to the firm) and the actual founding of a new venture. We observed connections between the "then" and "now" in the narratives, seeking to interpret the emerging episodes in terms of the meaning they had for the individual in making sense of his/her own "becoming" process.

We treated the narrative data as providing episodic particulars of the interviewee's autobiographical memory, hence forming the person's narrative identity from the overall script (McAdams 2013; McAdams and McLean 2013). The procedure allowed us to extract episodes which made sense of (subsequent) behavior, and which provided more detailed elaborations of perceptions of the self. In line with Linstead and Thomas (2002: 2), we saw the self as "constructed in terms of the conjunction of past and future, as an explanation of previous events as episodes in an unfolding narrative in a way that positions the constructor of the account advantageously for future episodes." Such an approach made it possible to explore the different qualities and meanings of certain events and experiences, in association with the founder-CEOs' selves as social actors and motivated agents (McAdams 2013).

Our study was initially data-driven. However, it took on abductive characteristics as we detected across the interviews commonly shared descriptions of the self and

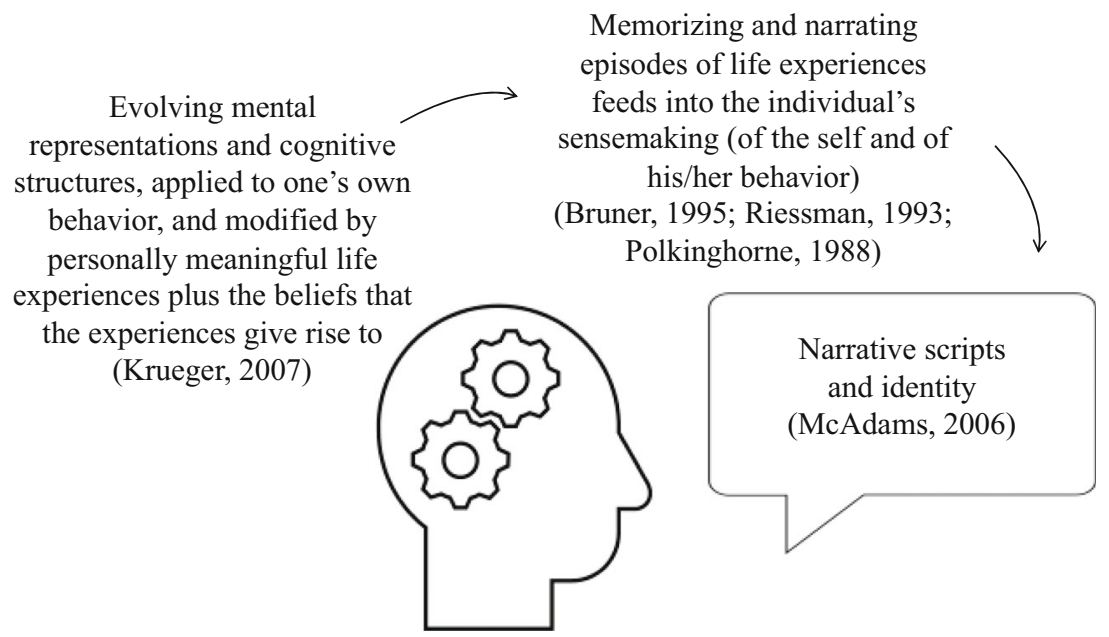

Fig. 1 Narrative scripts, viewed as tools for making sense of the self and of one's behavior in the processes of becoming an international entrepreneur 
of related behavior as (international) entrepreneurs - involving a need for autonomy, innovativeness, a risk-taking tendency, and proactiveness. Having interpreted these as means by which the interviewees made sense of individual IE behavior (as involving certain underlying mental representations of the self, acting in accordance with the overall IE script), we decided to go more deeply into the life experiences that constructed (Krueger 2007) and fed into such scripts (Gioia and Manz 1985; McAdams 2006).

With this in view, in following the sense-making of identities and behavior in the life narratives (McAdams 2006) of the interviewees, we treated the narrative interviews as wholes with a certain overall meaning, such that any single narrative episode would be better understood in the context of the other parts (Polkinghorne 1988). Eventually, having analyzed and compared the narratives (Polkinghorne 1988), we were able categorize the main features of the self, determining the experiences from which certain behaviors appeared to stem.

Due to the extensive nature of our data and analyses, it became clear that we needed to simplify the presentation of our findings. Table 2, thus, provides an overview of the features of the developing international entrepreneurial self within the entire pool of life narratives. Thereafter, we elaborate on the content of the table with reference to the narratives of five founder-CEOs. These five cases preserve and bring to life the narrative "devices" through which the individuals made sense of their experiences and of their identity (Birch and Miller 2000: 192).

\section{Findings}

\section{International entrepreneurial identities and behavior, as represented in five scripts}

Deriving from our narrative analysis (Polkinghorne 1988), Table 2 provides an overview of our findings regarding the narrative scripts by which the founder-CEOs made sense of the "who" and the "how" of themselves (constructing identities as actors in IE). It also sets out the developmental experiences that framed the interviewees' behavior in the evolving process of becoming and being an international entrepreneur.

As shown in Table 2, the Pioneer, Native, Diplomat, and Gambler scripts represent the "pure" types of script, within which one's behavior and sense of self is largely dominated by clearly identifiable and consistent features of self in relation to experiences. By contrast, the Eclectic script is of a more "hybrid" type (see Fauchart and Gruber 2011 for the terms "pure" and "hybrid"). In fact, the "pure" scripts could be interpreted as, overall, less frequent in their occurrence. They may, therefore, represent, to some extent, "outliers" in the overall spectrum. For its part, the Eclectic script (resembling a "hybrid" of the four "pure" scripts) has characteristics of dynamism within the founders' narrative sense-making regarding their behavior.

In the sections "The pioneer script: A visionary explorer of unmarked paths," "The native script: Maybe he's born with it?," “The diplomat script: Building bridges between people and the self," "The gambler script: Positive delusion is the name of the game," and "The eclectic script: Transforming behavior, initiating change," we elaborate how the five scripts presented in Table 2 (Pioneer, Native, Diplomat, Gambler, and Eclectic) are represented in the narratives of Kim, Mel, Per, Oz, and Joe. In the 
Table 2 Overview of the scripts revealed in the founders' narratives

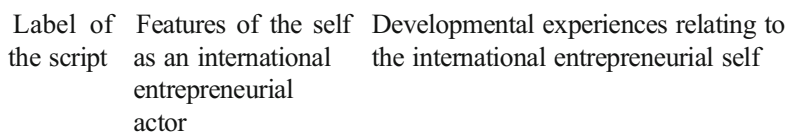

Label of Features of the self Developmental experiences relating to the script as an international the international entrepreneurial self entrepreneurial actor

Pioneer Visionary

Persistent

Altruistic

First-mover

Diplomat People-oriented

Mentor

Arbiter

Native Culture-savvy

Searcher for meaningfulness

Sociable

Gambler Positive delusion
Situations of becoming accustomed to look for global Kim trends with curiosity, and with the courage to do things Lars that others may not dare. Life experiences of going Cam beyond national borders, after new (life-)opportunities Val had contributed to an open mind.

Challenging events and related experiences, e.g., of losing personal health or facing external doubt and resistance. These later developed persistence, to do something that had not previously been done as a founder.

Situations involving a need to evaluate personal values while being obliged to put oneself on the line, sacrificing one's own privileges for a common benefit, while progressing along unmarked paths.

Events and actions in which one was conspicuous for doing something crazy or novel, while maintaining a brave and honest attitude.

Diverse cultural and social encounters. These were Paul challenging, but provided learning opportunities. They Bert involved required introspection plus interpretation of Gio interactions with people from different backgrounds. Stef

Through experiences of gaining help from others and developing know-how from previous work, personal learning was concretized. This brought about a genuine serving attitude, with a willingness to help less experienced persons through consulting, mentoring, or research.

Managerial experiences of constructing new knowledge of (international) human resource contexts over time enhanced a sense of responsibility, including a willingness to negotiate between diverse actors in cross-cultural situations.

Pre-adaptation to a "culture" from the very beginning (i.e., from being in multi-cultural family or as a "digi-native"), taking a cross-cultural context for granted.

Mel

Mack

Moss

Episodes of searching for and finding personal motivation, and a context that would foster a meaningful independent career.

Experiences in which the person benefited from a broad international social network, making it possible to spot venturing opportunities in the fluidity of one's proactive identity.

Situations involving "hyper-optimistic" of oneself and possibilities for success, plus opportunities for

$\mathrm{Oz}$ risk-taking that would provide the desired emotional thrill. This encouraged the person to keep reaching towards larger goals.
Founder(s)

expressing similar experiences 
Table 2 (continued)

\begin{tabular}{lll}
$\begin{array}{l}\text { Label of } \\
\text { the script }\end{array}$ & $\begin{array}{l}\text { as an international } \\
\text { entrepreneurial } \\
\text { actor }\end{array}$ & $\begin{array}{l}\text { Founder(s) } \\
\text { expressing } \\
\text { similar } \\
\text { experiences }\end{array}$ \\
\hline
\end{tabular}

\begin{tabular}{|c|c|c|c|}
\hline \multirow{5}{*}{ Eclectic } & Observant & $\begin{array}{l}\text { Evaluation of uncertain situations; developing the ability } \\
\text { to read the reactions and emotions of others, plus the } \\
\text { ability to keep cool in stressful situations. }\end{array}$ & \\
\hline & Competitive & $\begin{array}{l}\text { Interpretations of the business context as a "sport" of } \\
\text { logic and problem-solving, requiring one to keep a } \\
\text { close eye on a competitor's behavior and reactions. }\end{array}$ & \\
\hline & Transformative & $\begin{array}{l}\text { Experiences of being engaged in dynamic and changing } \\
\text { contexts, in which sensitivity was needed in one's } \\
\text { actions. } \\
\rightarrow \text { From a culture-savvy Native (from the very start), } \\
\text { moving towards the arbiter category of Diplomat }\end{array}$ & $\begin{array}{l}\text { Joe } \\
\text { Sandy } \\
\text { Miles } \\
\text { Sam } \\
\text { Hope }\end{array}$ \\
\hline & Initiator & $\begin{array}{l}\text { A continuous drive to confront new challenges, } \\
\text { enhancing an internal motivation to reach out to and } \\
\text { work hard for the next big thing, be it socially, } \\
\text { economically, or personally important. } \\
\rightarrow \text { A combination of becoming a visionary Pioneer, } \\
\text { searching for meaningfulness like a Native, and } \\
\text { making sense of the positive delusion of a Gambler }\end{array}$ & \\
\hline & Reflexive & $\begin{array}{l}\text { Having a profound sense of one's own self, but also the } \\
\text { ability to challenge these "beliefs" on the basis of } \\
\text { feedback from others. } \\
\rightarrow \text { Taking on experience-based characteristics of the kind } \\
\text { that differentiate an Eclectic "hybrid" script from a } \\
\text { more dominant "pure" script. }\end{array}$ & \\
\hline
\end{tabular}

"An eclectic reading of the scripts for international entrepreneurial behavior" section, we consider our findings in terms of how the scripts compare to each other and how a more comprehensive interpretation of developmental experiences becomes relevant in such scripts.

\section{The pioneer script: A visionary explorer of unmarked paths}

Our data contained the life narratives of international entrepreneurs who described themselves as forward-looking, possessing a proactive attitude and eagerness to move along unmarked paths throughout their career. They emphasized that the experiences of becoming an international entrepreneur can be challenging but also rewarding in terms of personal growth, as when one persists in believing in something that has not hitherto been attempted. Such narrations encapsulated what we call the Pioneer script. Here, entrepreneurial acts were made sense of in terms of being persistent and visionary in one's outlook. The narrative sense-making attached to such a script partly reflected the context of doing international business at a time when there was perhaps less external support for conducting and enacting pioneering ideas. To this extent, the Pioneer script involved sensitivity to the ideologically, politically, and culturally different times that an international entrepreneur might have encountered. He or she might have been 
forced either to give in, or else to fight for something personally meaningful, while developing an unconstrained yet legitimate status for one's company and one's self.

Kim is the founder of an international software company that has enabled knowledge transfer in large enterprises during organizational changes. For her, becoming and being an international entrepreneur was the foundation for managing sensitive organizational processes in conjunction with international business. Born in the 1950s, as the daughter of an engineer and the granddaughter of an entrepreneur, she was - perhaps unusually at the time - raised to consider herself to be as capable of doing things as her male peers. Over time, Kim preferred to take her own path, and she grew into being an independent young woman: "My brother always had a big gang around, still has [-] At school I only had one close friendship. But not this kind of big gang. That way, I've always taken more of my own path."

Despite beginning her business career at a time when the field was still dominated by men, she said that she was - and had remained — straightforward, even somewhat naïve in her actions. She had always seen herself as having the same possibilities as others: "I read about what people were saying, but I never thought it had anything to do with me."

From an early age, Kim had frequently taken responsibility, through her first jobs and her school committee. However, during high school, she encountered health problems. The health issues and related challenges had continued to appear. However, rather than indulging in self-pity, she said that for her they had developed "an exceptional ability to endure things," plus a personal value system and motivation: "I've needed to go through pretty tough crises. Life has led me in a sense ... that I've learned to look at things in a [certain] way ... [-] I have these deep values, that you have to give back what you've learned in life. [-] It's the feedback from giving that is the driver, the motive."

Having initially entered a career in the health technology industry, she constantly educated herself on various topics on and off work, seeking to gain a holistic view of her work. By the age of thirty, Kim was assigned by her employers to take over a whole division, including the task of taking the business to an international level: "Within a year they wanted to send me to North America. They'd never sent anyone abroad. [-] At that time there were no subsidiaries. No culture of doing it, but they were looking into it."

At that time, without any Internet or educational support from the organization, she was to enter the unknown world of international business, quite alone, and in the absence of modern technology. Based on her learning, she now stressed the importance of cultural sensitivity and experiential learning, even if one might have all the access in the world to specific information: "Now everything is on the Internet and it is open, and you find it there. Back then we had nothing. [-] But of course, if you don't have cultural understanding, it is good to acquire it from [abroad]."

Altogether, Kim's narration of being a woman in technology and business, leading internationalization, and taking on a position that had no previously established structures, expressed strongly a sense of being a "first-mover" in many dimensions. Eventually, after several decades in employment and years of independent business consulting, Kim became convinced that no real learning was taking place in the industry. She was determined to put her unique knowledge of her subject to practical use. Pursuing her pioneering idea with a team of experts, she created innovative software that concretized her knowledge and experience. People around her considered the business idea unlikely to succeed, and only few people believed in her vision. 
Nevertheless, she wanted to look far ahead to future opportunities and decided to take the risk.

Now, having invested all her finances in the business idea, she was seeking to expand her team to encompass a comprehensive set of skills and knowledge. On the basis of her various managerial positions, her years abroad, and her first-hand experience of innovative venturing and strategic renewal within the corporation, she described her path into entrepreneurship as multi-faceted:

I have led organizations into growth in many ways, I have been in [both] large and family firms, and in small firms in various roles. And I've been a consultant in a role where I've had to analyze things. [-] I have always been sort of a visionary. So that I foresee things in advance, I listen to trends, signals carefully. [-] This kind of understanding of global growth, knowledge and all of this, how to grow and take risks, and think of what comes next ...

From Kim's narrative, we see that experiences have grounded her beliefs in herself and her behavior as an independent, persistent, and value-driven international entrepreneur. She makes sense of herself through her early social relationships and independence from others' opinions (deriving from father-daughter relationship and sense of being equal with boys). Her sense-making also encompasses her self-assessed straightforward behavior and personality (i.e., her bluntness and naivety when she was growing up), her early and multiple experiences of going abroad by herself for work (i.e., summer work when she was a teenager and being the first woman as a global sales manager in an internationalizing company in the 80s), and the tough times she went through when starting her own business (i.e., sticking with an idea that people said was too difficult). Throughout her story, Kim continued to strengthen her international entrepreneurial self through an altruistic quest of putting her personal experiences to use for the good of others.

\section{The native script: Maybe he's born with it?}

A "native script" reflects the position of founder-CEOs who are internally driven by awareness of the necessity of doing international business; also by having an entrepreneurial mindset and the privilege of being internationally and/or entrepreneurially oriented from an early period in their life. Assuming that such a person also has a personal motivation for entrepreneurial practices, our interpretation of the native script fits well with the behavior of a "born global" entrepreneur, i.e., one who has the internal abilities to adapt easily to various global "cultures" of business (by being, e.g., a "world citizen" or a "digi-native"), and to a career in which they become more and more embedded. Such characteristics - in conjunction with the push of personal interests and education and the pull of broad social networks, accentuated by the technological advances of the time - enable the person to construct a flexible identity that will endure both personal and social scrutiny.

Mel is the co-founder of a small software company. It does consultancy work and facilitation of communication and knowledge transfer in overseas projects between large multi-national clients. For Mel, both becoming an entrepreneur and being international is self-evident. A strong source of his sense-making is located in his multi-cultural 
family background and his digitally savvy generation. Having been born into a multicultural family, Mel had dual citizenship at his birth and was exposed to three different languages.

Mel stressed his family and generational foundation as useful in his international encounters today. He estimated his willingness to speak foreign languages and to deal with strangers as above average. Moreover, in his opinion, modern-day business ought to be international from the start and should follow other global developments: "One must have the international grip from the start. If one aims to do up-to-date business at all." Like many of his age-peer international entrepreneurs, Mel enjoyed the benefits of being in the first waves of digitalization. He acknowledged the advantages possessed by the current digital-native generation and their potential in fostering entrepreneurship: "Digitalization, it has, if you like, concreteness in it, which has made it possible for a 20-year-old man or woman to do international business anywhere in the world."

Mel's entrepreneurial journey began at the end of his college years. He displays some characteristics of a born entrepreneur, insofar as he became an entrepreneur fairly quickly, without any notable prior working experiences. However, the spark to the cofounding of a company came from experiences in other environments. Growing from a fairly shy boy to a sports enthusiast and to a confident performer in his city theater in his early adulthood, Mel started to find his internal motivation for an entrepreneurial career before became he aware of it himself:

At the time of my studies, these experiences, like establishing the (sports) team, and some courses, about establishing a firm, where you create your own business idea and gather substance around it ... It was like actualizing a dream. [-] that's when it gave the spark, like, "damn, how cool was that, managing to do such a thing!" At the end of my studies, I had already decided that I'd become an entrepreneur.

Without having the kind of definite entrepreneurial family background that can often spark a positive attitude to work and an entrepreneurial mindset (or the opposite), Mel had been raised to work hard and always to do his work as well as possible. His farmer grandfather had engraved in Mel the image of working for one's own livelihood and aspirations, and Mel could not imagine working for someone else's dreams. He had recognized the importance of personal passion in working and had experienced great joy in creating something meaningful for himself. Despite a deepened knowledge of network management gained during a short period of employment at the university, his internal motivation, personal desires, and ideas were realized only after he became an entrepreneur. During the short period of employment after graduation, Mel had established trust with clients who shared broader visions with him. Conveniently, all of them were willing to take the risk of starting a business collectively:

I am definitely not an entrepreneur doing it all by myself. [-] When we three established the company, we had strengths that were complementary, at least when it came to my own strengths. They probably could have made it by themselves, but I would have not survived. I am the kind who wants to do things together ... I really enjoy the success which we can reach together. 
In Mel's narrative, experiences from his early childhood and his studies were profound in making sense of the self-evident path by which he became an international entrepreneur. Mel's memories emphasize his birth into a multi-cultural family, respect for "entrepreneurial" work (i.e., a farmer grandfather as a role model), being part of proactive teams (i.e., in playing in sports teams or acting in the theater), finding the spark to establish a team on his own (i.e., founding a sports team), and having people as mentors and partners around him from the start (notably a professor in the university). Yet, overall, the most critical developmental experience in Mel's case was surely that he was born into a multi-cultural family and that he heard and spoke several languages at an early age. Furthermore, the episodes of Mel's narrative demonstrate the IE journey as a more or less self-evident career choice, one that was both externally driven (involving international business, digitalization, and university, clients) and internally driven (involving a multi-cultural identity, personal dreams, and motivation).

\section{The diplomat script: Building bridges between people and the self}

According to our interpretation, some of the founders' identity constructions and behaviors unfolded according to what we call a "diplomat script." The diplomat script seems to gain momentum from personal cultural and social encounters that both challenge and provide learning opportunities, constructing knowledge of the international context over time. As seen in Per's narrative in subsequent texts, this script manifests a developing path of internationalization, arrived at through introspection, with interpretation of interactions with people from different backgrounds along the life trajectory. In this sense, the diplomat script seems to be grounded in people-oriented experiences. It fits well with the demands of contemporary internationalization and of entrepreneurial careers that build on social relationships and networks.

Per is a founder-CEO and partner consultant in a knowledge-intensive business service firm. For him, IE is about helping domestic and international companies (smalland medium-sized) to develop their international services. Per was born into a normal working family without any initial entrepreneurship influences. However, there were pressures from his father and grandfather to perform to the best of his ability, personal challenges in balancing between studying and working, and eventually, the responsibilities of becoming a father in early adulthood. These were factors that developed Per into conscientious young man.

As a challenge-seeker, Per said that he easily became bored. In learning to balance his life between being a father and building a corporate career, Per had already gained extensive managerial experience by his thirties. His working career in different corporations had up to the present given him diverse work experience, both domestic and international: "I left [company X] when it started to feel so ... maybe boring is a wrong word, but easy? And I saw that [company Y] was looking for a candidate to go to North America. And I sought the position, or applied, and got hired."

In addition to his extensive international experiences, Per increased his "intrapreneurial" orientation and his pursuit of strategic renewal in the corporations where he was employed. However, he emphasized that these involved lower risks than entrepreneurship, to be undertaken either by starting up a business or investing in buying one. He further elaborated on the motivating aspects of entrepreneurship, how he worked without counting the hours, seeing needs for change where others refused to 
see them: "Maybe I've always been a bit workaholic. That I haven't counted the hours I've worked. Maybe in that sense I've been an entrepreneur ... or entrepreneurially oriented."

Freedom was a strong element in Per's narration. The way in which he liked to be led himself was the way he liked to lead others. In attempting to be a leader rather than a manager, he had been determined to give his employees autonomy. He saw it as necessary not to control people too much: "Maybe it has been one of the weaknesses in my leadership that I haven't followed up enough ... or controlled. Control is exactly the kind of management that I don't like."

He had met his father's international business friends from an early age, worked as an expatriate for several years, and had specific experiences of being challenged by cultural differences among colleagues. He had thus grown to appreciate the need to encourage efforts for international relations in the workplace:

In some cultures, they do things I can't accept, in a sense. But, it becomes understandable, if you give it a chance. [-] there are different kinds of people and different cultures and different kinds of ways of doing things and none of them is the right one. [- $]$ The world view of the other person may be a somewhat different from one's own, and I'm not sure if my own is any better.

Furthermore, in reflecting on his growing international interests and mindset, Per indicated the connections between his experiences abroad and intuitive urges in his managerial decision-making. The fact that he took experience and enthusiasm for granted influenced his evaluation of ways to proceed: "At that point, I had lived abroad a good period, and somehow it felt natural. [-] I thought I'd try at an early enough stage to internationalize its operations. I didn't really think about it. Maybe I should have."

Despite encounters with various challenging situations and mistakes as an international manager, none of his experiences had made him regret his engagement with international business. In fact, those international experiences had changed him into what he was now and had given him the internally strong desire to seek development in international business, especially the development of small firms. Eventually, when one employment contract ended, Per found himself creating himself a "new" career as an entrepreneur, putting his knowledge and interests to specialized use: "Know-how is maybe the wrong word [-] but it has become natural for me in the course of many years. Then, in this firm, perhaps one aims to advance what one is good at. [-] First one ends up in international tasks, then it feels natural, and then one seeks to take these on."

From Per's narration, we can extract his experiences of pressure to work hard (from parents and grandparents expecting a good performance in school), exposure to cultural diversity from early on (from his father's international work colleagues and a cultural training program), the need to balance work and family life (returning from being an expatriate), and leading internationalization (as an employed manager). In fact, Per had been continuously handling situations which required balancing acts. Overall, he became an international entrepreneur after and through various life and career transitions. The founding of the company eventually emerged as a concrete service, concretizing his motivated approach to work, networks, and know-how from previous international assignments. Through his own learning of the international field, he had gained the motivation to help and serve less experienced peers, via his consulting, mentoring, and research-related work. It 
was perhaps no wonder that such a committed person would find it fulfilling to contribute in developing the internationalization processes of small firms, having himself had life stages of being an expatriate and a manager of a small firm.

\section{The gambler script: Positive delusion is the name of the game}

The gambler script manifests the behavior surrounding risk-taking amid the uncertainties of founding an INV. If the script is followed through, taking on calculated risks provides the thrill of the game. Moreover, as in the case of $\mathrm{Oz}$ (see subsequent texts), an international entrepreneur who takes on the gambler script tends to be one with big dreams. Thus, to take the example of $\mathrm{Oz}$, reaching millions of online followers worldwide is both the motivation and the means for international venturing. As one might expect from such individuals, a pre-eminent characteristic is intelligence, applied to dealing dispassionately with human cognition and emotions. Thus, the founders following this script seem to have taken on responsibility for their risk-taking actions, as an integral part of their personality. If one disregards the negative connotations of "gambling," the narratives highlight the positive aspects of such behaviors. IE makes sense as a kind of "sport" of logic and problem-solving, one that makes it necessary to keep a close eye on competitors' actions and reactions. International entrepreneurs following a gambler script seem to have good abilities to handle emotions and manage their own reactions in stressful situations. It may also be that without the slightly "delusional" mindset, the interviewed founders in this category would never have gone beyond the average level.

$\mathrm{Oz}$ is the founder of a small online gaming company, one that brings scientific knowledge to the wider public. His sense-making narration of his path to becoming an international entrepreneur emphasized the logic of psychological human development. $\mathrm{Oz}$ was born and raised in a family that encouraged him to think independently and responsibly. "Verbal debates" at home developed his argumentative skills, a strong interest in sports and games from early on created a competitive drive, and an eagerness to continuously read and learn more gave him a foundation to holistically understand himself and to reflect on the world around him. He acknowledged personal experiences as important in shaping his thinking and values (i.e., being socially responsible) and placed an emphasis on parenting, society, and a university education in natural sciences.

Oz mentioned that his early background in sports had influenced his move to becoming an entrepreneur. Since he was seven years old, he had constantly played either soccer or ice hockey. Having participated in sports at a high level, he reflected on an early dream of becoming a professional athlete: "This might not be a surprise, but many entrepreneurs have sports in their background. And why sports, it might be something with the goal-directedness. Maybe competitiveness. [-] I have always loved games. [-] And I was very goal-directed already at a young age."

On coming into his twenties, Oz realized that he could not create a career in sports. At this time, he discovered online poker. Oz now liked to link this to his philosophy of wanting to reach goals, and his longing for action: "[Online poker] was this really intriguing mode of sports, competition, and games, and then, it was also logical. I've always liked math, physics, these kinds of logical subjects, problem-solving things. It was so fascinating. This combined it all.” 
After a relatively successful start with his online poker career, Oz decided he did not wish to continue down that road. He did not wish to become networked with the people he was meeting online and at events of the industry, as he could see how certain values held in that community would have gradually altered his own perspectives. Along with pursuing a degree in natural sciences, Oz had an idea developing in his head. This came to fruition after a motivational speaker, who was also a successful entrepreneur, pressed his "emotional buttons." Less than a year later, Oz had established his own company and had managed to book a meeting with a leading online gaming company in the country. During the first year of his company, Oz's major realization was that he had to concretize the ideas that he had in his head and to go beyond merely developing and learning new things in theory. Finding a co-founder who had the same love for the games as $\mathrm{Oz}$ was a turning point in getting his ideas into a realizable form.

For $\mathrm{Oz}$, his internal drive of being an entrepreneur could be compared to that of an athlete. In soccer, one can see the desire to succeed in the way the players fight for every ball, without any certainty of achieving a final result:

When you have an uncertain end result, you still very strongly believe that it will happen. You have no proof that it will, but you believe that it will happen. It links to when you present a vision to the investor, saying that such and such will happen, because we'll do such and such a thing. You have the arguments for it. [-] It's really hard to fake it, it shows through [-] Everything is based on this kind of strong manipulation of people.

(Authors' note: Term "manipulation" is a direct quote and the context is the convincing of people of a grandiose vision.)

Describing himself as a person who rather makes intellectual guesses and develops his own opinion of where things are headed, Oz was skeptical about looking into the past and at the fluctuation of trends. Relating such a behavioral orientation to the dynamics of poker, he talked about forecasting, or predicting the future:

The predictions are based on who you play with. The person you're playing with is much more important than the cards you play with. Who you play with, what they are thinking, their backgrounds, why they play and all sorts of things. [-] In a way, entrepreneurship or visioning, or anything, it's exactly the same.

$\mathrm{Oz}$ argued that of more importance than intelligence is how you handle your emotions. In gambling, as in life in general, one ought to understand and process feelings of failure, loss, success, and the entire spectrum of emotions. One must recognize what is fear-oriented and what is desire-oriented: "It's far more important than whether you can, as if were, logically do something. [-] That's what I strive for, reflecting on how I react."

For Oz, having an international start for the company was self-evident, due to the online nature of the gaming industry. However, realizing that he lived his own childhood in the $80 \mathrm{~s}$, Oz indicated that it was impossible to compare things now with what they would have been back then. The changes brought by the Internet have made "international" a starting point, "the default" position in any business. One interesting point was that though his poker career had been global by default, for Oz, traveling was 
never in itself a large part of the deal: "I think if I had started to travel, it would have been addictive in many ways."

It was clear that $\mathrm{Oz}$ had found a career in which he was not just doing something for a living. His motivation was the passion for the game:

In poker they call it "investment in loss," meaning how much we are able to invest in the losing and learning process in the game, in everything, including in life. I realized I was doing something that I loved tremendously. I believed I could break through at some point and I was willing to accept quite a lot of loss, in that I could learn from it at some point.

Showing admiration for internationally known entrepreneurs, such as Elon Musk ${ }^{1}$ and Richard Branson, ${ }^{2} \mathrm{Oz}$ talked about the positive "delusion" he would foster in being an entrepreneur. One's belief may not really correlate with the present or "what is," but the positive illusions of "what could be": "It's really interesting how many entrepreneurs want to live out of that. That they can dream big. [-] in a way, when we look at people who have succeeded in life, as measured in many ways, it is dependent on your values, what you see as valuable."

Oz's narration included the experience of an intellectually challenging childhood (family debates), being attracted to competition (playing games from an early age), and being intensively engaged in an environment of personal risk-taking, plus the emotional involvement associated with it (online poker). All in all, his narration emphasized the importance of a "delusional" mentality, plus an understanding of emotions as the basis for people's behavior in start-up venturing. Containing plentiful metaphors from the poker and sports world, references to successful entrepreneurs, and mention of phenomena in the natural sciences, his narrative stressed his "positively delusional" outlook on the future, together with philosophical attributions regarding his engagement with entrepreneurship. Oz's story, incorporating notions of both nature and nurture, aptly illustrated how personality, upbringing, personal behavioral choices (e.g., resisting addictive environments), and decisions on education had all affected the behavior that unfolded in the narrative.

\section{The eclectic script: Transforming behavior, initiating change}

In the eclectic script, many of the founders were both eager to and able to learn, with a strong willingness to be transformative in the dynamic and changing international business context. In addition to an internal motivation to initiate and to work diligently for the next big thing, these founders were reflexive persons, willing to reflect on and re-interpret their interaction with their (social) environment on the way. Manifesting a profound sense of one's own self-but also the ability to challenge assumptions following feedback from others - an eclectic script seems to give people possibilities to adopt a myriad of approaches within the complexity of IE.

\footnotetext{
${ }^{1}$ Elon Musk is the founder-CEO of SpaceX, co-founder and CEO of Tesla Inc., and co-founder and CEO of Neuralink.

${ }^{2}$ Richard Branson is the founder of the Virgin Group.
} 
Joe is the founder of a company that develops software solutions for education modeling. His narrative could be seen more or less as a hybrid version of the behavioral elements found in the four narratives mentioned previously. In general, the path to international entrepreneurship had been paved with both challenges and beneficial events that had affected his views on how he saw things coming together.

Born into a fairly small town, Joe was only 16 when he moved on his own to a larger town. Joe's narration on his youth was marked by independence from early on. Making sense of his personality now, Joe thought that he had found a good fit between his autonomous behavior and the work he was doing.

In recounting more details of his youth, Joe made sense of himself as a person who always wanted to come up with something that no one would have expected: "I've always been like that, I get bored, I need to do something new. Change something, start something totally new. It marks my actions a lot. I'm the kind of person who wants to try out things. [-] I did things no one was expecting. Good and not so good."

In line with this (here, resembling the pioneer script of doing something novel, and also the native script in terms of the desire to do something personally meaningful), Joe saw himself as an initiator, with the drive to create something new. On the other hand, he described himself as being the kind of person with a fearless attitude towards the things he had decided to do. New challenges, embedded in uncertainty, had become one of the main drivers of his actions. Here, he manifested a resemblance to the gambler script:

I think actually, that quite many of those who have succeeded in growing something big, have something wrong in their head too. They don't think like other people. It's some kind of fearless orientation, or maybe it's just stupidity, I don't know, but it's the kind of thing that means you are not afraid. If you don't think about it too long, you may actually get something done.

The internal drive of to try out new things led Joe to set up a small two-person ITsupport firm with a friend, while they were finalizing their engineering degrees. It was something that he was really enthusiastic about. In the manner of a native, Joe had grown up in a generation that enjoyed the increasing availability of information technology, forming the foundations for digitalization. After graduation, Joe and a couple of his friends could not find jobs in their home town: "We decided to do things differently, to found a company and sell our own thing. [-] We didn't want to move from home. [-] There were four of us. One left during the first year, because he couldn't handle the pressure of not knowing if there was money coming in or not."

Becoming aware that surrounding companies, founded locally, had survived, and were striving internationally, Joe gained the confidence to start venturing. He perceived that one could do global business with a local attachment. From this realization, "international" emerged as a self-evident dimension to his venturing: "I saw that there were other international firms, successful IT firms who had made it, so why not us. One local company in particular was a great inspiration. [-] When I saw that, I was like, why not. They're no different from us, the same kind of guys, and they have made it in the world." 
Referring to having played with a cousin who had a different national heritage as a kid, Joe did not consider being international as something extraordinary. Rather, it was just something that had to be understood: "I've always thought that people are equal and the same, but they're different because they've been born into a different culture and stuff."

In addition, Joe's contextual embeddedness intertwined with his growing ability to navigate between different managerial perceptions, thus following a diplomat script. In broad terms, Joe's narration indicated his willingness to transform and adapt as needed in his IE journey. In learning to lead a rapidly internationalizing firm, he had formed a strengthened understanding of himself, the international (business) environment he was working in, and the people he was leading. Manifesting traits similar to Per's motivation to understand, help, and serve the people around him, and to connect with people of different backgrounds, Joe reflected on in his willingness to learn, and to analyze how to lead an international firm better: "You cannot blindly lead this kind of a company. It's not the kind of old-school management like in a metal shop. You have to create personal relationships with key people, and they need to trust you, and you them." In addition, bound up with Joe's social context of IE venturing, he had friends with similar job positions. Thus, he could reflect on phenomena behind and beyond the daily issues he was encountering in business.

Another behavioral aspect of the script, as revealed in Joe's narrative, was his tendency to make fairly rapid decisions. This became apparent in his reflections on both himself and the firm. Joe's preference for quick decision-making seemed to be driven by a deep tendency to become "bored," to need change: "That boredom has driven me further. [-] Two, three years and we change something. [-] It's probably one of the things that it demands, you have to be able to constantly change. If you don't like change, you shouldn't be doing this." At the same time, Joe described himself as having something of an attention deficit disorder, ${ }^{3}$ since his way to get things done was to have too much going on at the same time. This gave him the right amount of pressure to complete the tasks at hand.

On the other hand, Joe said that he did not like surprises. Hence, he constantly considered "worst case scenarios" to deal with feelings of uncertainty. In some respects one can relate this to the Gambler script, which involves keen observance of the possible reactions of others. It is interesting that in making sense of the global landscape of his business, and the implications for his work, Joe found it hard just to settle for what he has achieved. Again, as in the Gambler script, Joe's attitude showed a certain degree of "positive delusion," insofar as there was always something more to conquer on his IE journey: "A person has climbed to the top of the mountain, but then, he's not at all excited about the fact that he's up there. He's just thinking "what should I do next?" There is always something [-] will not even take a cup of coffee to celebrate it, instead I'm already thinking of the next big thing."

\footnotetext{
${ }^{3}$ Attention deficit disorder (ADD) is a developmental disorder that is often marked by persistent symptoms of inattention or by symptoms of hyperactivity and impulsivity, or by symptoms of all three. It is not caused by any serious underlying physical or mental disorder.
} 


\section{An eclectic reading of the scripts for international entrepreneurial behavior}

Identification of a Pioneer, Diplomat, Native, Gambler, or an Eclectic script leads to a multi-faceted perspective on what it is to be an international entrepreneur. The scripts shed light on individuals' interpretations of the essence in IE behavior. Figure 2 sets out a comparative framework for the five scripts, providing an overview of their strengths, plus situations that pose challenges for the individual who follows such a script. We also identify certain learning points that are crucial for each international entrepreneurial actor.

Overall, with regard to what it means to be an international entrepreneur, the five scripts show both an internal orientation (as with $\mathrm{Oz}$, in following his internal "delusional" attitude towards executing new ideas) and an external orientation (as with Joe, in having to adjust his managerial approaches when his staff extends beyond borders). To some extent, all of the five scripts reflect IE behavior manifesting an internal drive to take on challenges, to seek freedom in working, to utilize one's knowledge, and to adjust or align behavior according to different (social) contexts. All of the scripts contain various similarities and differences.

The Gambler script prioritizes making one's mark in a bold, daring international venture, while doing the things one enjoys most within a value-driven, independent quest to put one's personal experiences and understandings to good use. In a similar way, the Pioneer script manifests motivation by large deeds, perhaps done in an altruistic way, helping one's "followers" to venture into a better world. A Pioneer develops a proactive and visionary identity in pursuing international and entrepreneurial opportunities. A Gambler, on the other hand, finds a thrill in setting "delusional" goals, forecasting the future, and making reactive intellectual guesses about different environments - in other words, the Gambler interprets his/her own reactions and those of others, in specific situations where people come from different backgrounds.

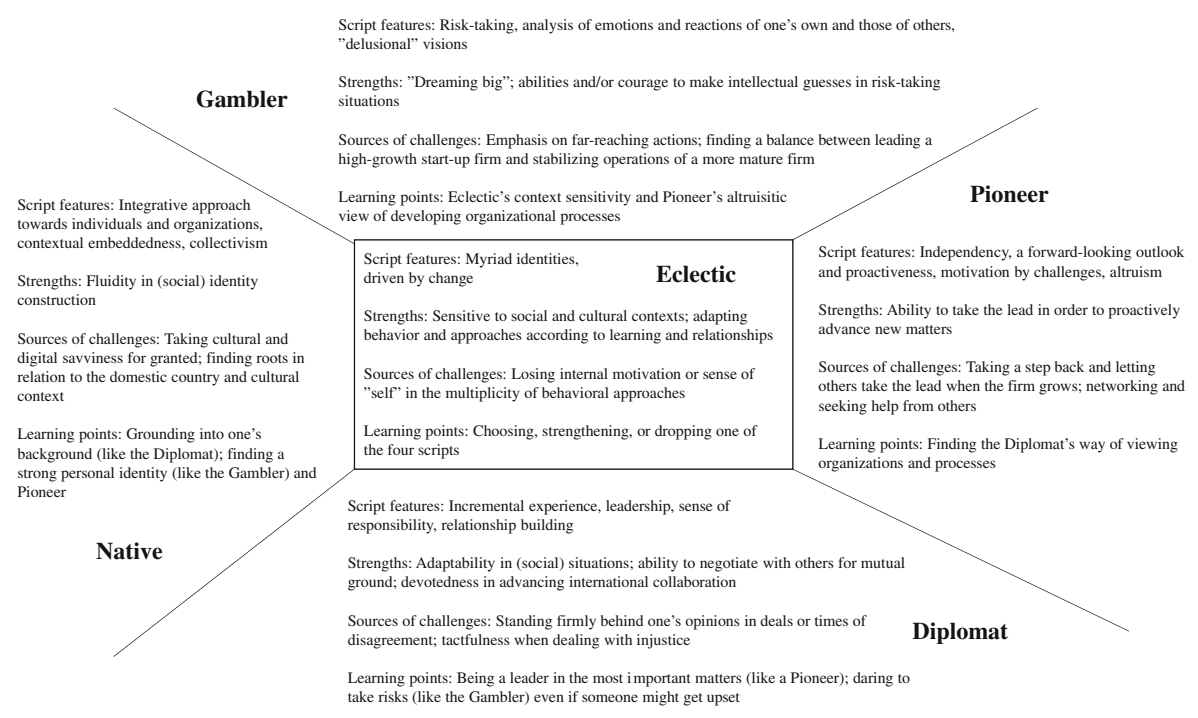

Fig. 2 Comparing the five scripts of international entrepreneurial behavior 
In comparison to the Pioneer script, the Diplomat script, too, demonstrates a strong motivation to advance and develop international business, and utilize personal knowledge for the common good in the matter. However, one can see a Diplomat's approach to leadership and international relations as involving matters for negotiation in dialog, whereas the Pioneer is a "spearhead" for actions, in other words the person showing the way. If one adheres more to a Diplomat script, one will devotedly advance international collaboration, showing sensitivity and tact when dealing with others. Correspondingly, one who is drawn to the Pioneer script could perhaps learn ways of approaching people and organizations from a different culture in a more diplomatic manner-even while maintaining elements of straightforward pioneering behavior. Then again, in contrast to a Diplomat, who emphasizes the developing nature of international inclusiveness and leadership, a Native will pursue the IE journey as a natural path, based on an internalized entrepreneurial mindset and an inherent multi-cultural identity.

A founder with a Diplomat script may face difficulties in holding to a firm position in relation to other actors in the venturing processes. By contrast, a founder with a Gambler or a Pioneer script may find difficulties in taking a step back with their competitive visions, letting others take action when a firm grows or when they could profitably seek help from others. There are challenges in the Native script and possibly in the Eclectic script also, in that one may not truly identify with anything, or with any career. The dynamic working contexts may appear too complex to grasp, and there may be increasingly numerous options and venturing possibilities. All this could result in too many contradicting identities, or in no identity at all-producing internal chaos, and, at worst, burnout.

\section{Interpreting the contextual underpinnings of behavioral scripts}

Modern life has elements that are more or less irreversible. These involve the exponential development of technology and disruptive innovations, multi-cultural environments as default situations (i.e., in families, schools, workplaces), and the requirements for current generations to pursue an (international) entrepreneurial career in times of increasing uncertainty. The most intriguing differences in the scripts relate to developmental experiences pertaining to particular contexts.

The Pioneer script seems to be constructed over time in relation to developmental experiences in relation to historically bound contexts (i.e., ideological, political, economic, or cultural contexts) which represent certain broader agendas for behavior in a society. A founder following a Pioneer script will have developed a strong sense of the "self" in the context of international business (whether through "naivety" or through overall stability in the self-assessment of who the person is). He/she is able to operationalize personal visions without doubts encroaching from external voices (notably those of colleagues, business networks, gendered discussions).

The Native script seems to involve assumptions stemming from generational embeddedness (in a multi-cultural family, in the digitalization of business, in a contemporary working culture). Through such embeddedness, the person has developed certain IE behavioral tendencies. Persons with a Native cognitive script do not need to specifically identify with being either "international" or entrepreneurial. They take these phenomena as self-evident in the contemporary global business context. Becoming a Native in IE actually expresses a sense of freedom in constructing a global 
identity within the modern international business environment - an identity that is perhaps less and less fixed to any particular context or country.

The Gambler script stresses the "emotional context" of one's sense-making, with behavior being related to affective experiences. The founders of risk-taking small firms who follow a Gambler script have the advantage of an emotional affect grounded in a rapid start-up scene. Within this context, emotionally intelligent founders can attract investors who seek innovative courses of action; these may themselves be "delusional" entrepreneurs, seeking to revolutionize the world.

The Diplomat script seems to involve making sense of social interactions. Hence, the dialogical approach within a Diplomat script favors learning from interaction-oriented challenges, such as the culturally and socially diverse situations IE inevitably imposes on founder-CEOs. Such a script serves as a guidepost for customizing approaches in dealing with international business networks. It also encourages moderation in entrepreneurial opportunities.

All the scripts have certain beneficial aspects. Nevertheless, given fluctuations in trends, the emergence of disruptive innovations, and the necessity of internationalization, "hybrid" scripts have considerable advantages. They favor adaptability to change, with possibilities to adjust approaches to the varying demands of IE over time. Hence, in preference to internalizing any one fixed type of behavior or identity, there are good reasons to pursue dynamism in identity work, generating novel understandings of the "cycle of interactions with elements of the surrounding environment" (Randerson 2016: 582).

\section{Discussion and conclusions}

This study examined the life narratives of founder-CEOs, seeking to explore the developmental experiences which, over time (Krueger 2007), feed into the IE behavior of international entrepreneurs. It showed how individuals engaged in the IE journey and constructed identities relative to becoming and being international entrepreneurs. With this in view, we have retreated from viewing IE behavior as a firm-level construct (Miller 2011), reinterpreting what it means to be an international entrepreneur, and whence IE behaviors originate. Hence, considering entrepreneurship to be the product of how entrepreneurs make sense of the world (Steyaert and Katz 2004; van Burg and Romme 2014), and seeking to bridge various dimensions of the phenomenon (Gartner et al. 1992; Randerson 2016), we embarked on an exploration of the developmental experiences of founders (Gioia and Manz 1985; Jones and Casulli 2014; Krueger 2007).

Via the eclectic readings of our findings, we contribute to IE literature on individuallevel IE behavior (Coviello 2015; Nielsen and Lassen 2012; Prashantham et al. 2019; Sarasvathy et al. 2014) in a number of ways. Via our interpretation of a Pioneer script, we argue that exploration of the developmental experiences of founders leads to recognition of the role of different historically bound contexts (ideological, political, or cultural discussions within society) in IE behavior. These contexts affect the processes of becoming an international entrepreneur, subsequent identities, and actions taken. We point to individuals who have developed a strong sense of self by following a Pioneer script and have gained a corresponding identity (i.e., persistency). This has stood them in good in unfavorable contexts (such as being a woman in a male- 
dominated business field) or in launching a career in an externally uncertain situation (such as during economic recession). The Pioneer script has made them more autonomous, unheeding of external voices that would seek to discourage their personal aspirations on the IE journey.

The Native script adds to our understanding of the generational contexts that certain IE behaviors and identities stem from. According to our interpretation of the Native script, we suggest that by looking at the generational context (such as the current one), we can better understand why some are savvier than others in navigating the global business environment right from the word go. Having the advantage of being more, e.g., culturally savvy, or being a native of the rapidly digitalizing world (Palfrey and Gasser 2011), individuals with a Native script manifest embeddedness in their generations.

The Diplomat script in particular illuminates the role of social interaction and networks (Evers and O'Gorman 2011; Ellis 2011) in IE developmental experiences. In our interpretation of the script, we draw attention to international entrepreneurs being on a socially constructed IE journey. Within it, individuals make sense of their identities - identities are formed under the influence of their international relationships, the meaningful people around them, and the effects of their own behaviors on those relationships. As we see in the narrative data, a Diplomat script adds to our knowledge of how certain experiences (such as getting help from others) develop a genuine serving attitude and influence the development of individual IE behavior and eventually the firm (e.g., when one becomes a mentor or sets up a consultancy business).

From our reading of the Gambler script, we suggest that the behavior of international entrepreneurs may be developed through experiences that are emotionally affective. An emotion-oriented perspective is helpful in recognizing the developmental experiences of founder-CEOs with a tendency to take risks, plus a drive to compete and achieve big outcomes. One can say that emotional factors are the key to their underlying motivations, and to the logics behind their risk-taking. However, as revealed in the Gambler script, success is not just a matter of big gains; it also involves learning the game in terms of human nature and testing one's own abilities to handle stress in situations of uncertainty. Hence, going beyond common views of international entrepreneurs as "mere" risk-takers and high achievers, we would argue that it is crucial to see founders as emotional — as much as analytical — actors with dispassionate ways of handling their own (genuine) emotions, and those of others. These factors are pre-eminent in their venturing over time and form the background to their behaviors in their IE ventures.

The study also addressed the importance of studying the founders' sense-making and identity construction as the undercurrent for IE behavior (Coviello 2015; Hannibal 2017; Jones and Casulli 2014; Sarasvathy et al. 2014). Accordingly, it sheds light on how, within IE, the "I" (both international- and identity-related) becomes manifested at different times and through different contexts (Buttriss and Wilkinson 2007) for individual experiences. At the individual level, as perceived through a life-narrative perspective, IE is a story, manifesting the very essence of becoming an international actor on the IE journey. The individual's IE identityplus related behavioral orientations, attitudes, intentions, and self-efficacy in building an international self as an entrepreneur-evolves over time and definitely continues to evolve. The evolution is based on meaningful experiences such as interactions with people from different international backgrounds (as with the 
Diplomat), the "historical" timing of an international employment relationship (the Pioneer), emotional arousal from global scale events and phenomena (the Gambler), or generational transitions (the Native).

According to our interpretations, IE behaviors are interpreted in relation to events, actions, and personal self-efficacy within the social and cultural contexts in which the behavior takes place. The result is that founders have different (experience-bound) perceptions of their own motivations, orientations, and capabilities when addressing different contexts relative to their IE journey, and responding to the demands these contexts have posed on them as individuals. For example, following through a Pioneer script, visionary ideas and personal persistency are motivating features when overcoming various challenges. In the Diplomat script, one's people-orientation stresses importance to act as an arbiter between people from different cultures, whereas, in the Gambler script, one has developed capabilities to read the reactions of others and to handle one's own emotions during the IE journey. Hence, individuals seem to define their international entrepreneurial identities (and related behavior) by means of their earlier experiences and to adjust them according to what they draw from these experiences, personally.

Considering possible limitations, related in part to the novel aspects of our narrative approach to IE, we suggest that future research directions should follow up by (a) looking in greater depth at the individual scripts and their broader implications; (b) making cross-cultural (or industry) comparisons between narrative scripts and founder-level identity constructions (involving the assumptions and beliefs that such identities embody), plus the different contexts (institutional, political) in which they emerge; and (c) looking in even greater depth at the "international" aspects in the process. This could involve looking more specifically, and, also longitudinally, at the emergence and development of the individuals' own internationalization. Furthermore, adding to another interesting research path involving the significance of (prior) social interactions of international entrepreneurs (e.g., Nowiński and Rialp 2016), one could pay more attention to the experiences of founding team members and the different narrative scripts they follow in their identity constructions (e.g., from experiences of being of different ages and nationalities and with differing expertise and education). Accordingly, there could be further exploration on the interpersonal relationships (involving the interaction of different identities and scripts) that could enable, develop, or even deter IE processes. This would be of most relevance prior to and around the founding of an international venture.

Entrepreneurship literature has long advanced "grand narratives," facilitating a spread of beliefs in what entrepreneurship is, or perhaps should be (Rehn et al. 2013: 546). This kind of narration is also how the field and the practice acquire an "identity" (Rehn et al. 2013: 546). It is true that constructs of entrepreneurial behavior that stress objectivity may be useful to scholars and practitioners as useful devices for interpreting the performance of small, early-internationalized firms. Nevertheless, we could also take advantage of a complementary perspective, involving developmental experiences of internationalizing behavior. In addition, if we are aware that the stories we tell of IE can be either productive or destructive, either useful or disruptive (Rehn et al. 2013), we can learn how to become usefully self-reflexive, with beneficial outcomes for IE processes. 
If we look at IE behaviors via scripts, we shall be able to not only to describe, but also to explore more deeply the beliefs of individuals (and perhaps societies) regarding who they are, who they should be, and how they should behave. We would argue that overall, there could perhaps be more variation in the public narration of IE (i.e., in the media and educational institutes). After all, the phenomenon can remain on a somewhat "out there" level, as perceived by the ordinary person, if the discussion remains at the firm-level, employing only numbers and "faceless" performance indicators. Moreover, we suggest that educators should become aware of which scripts in IE are constructive, contributing to the developmental processes of (potential) international entrepreneurs, and which scripts might gradually move development in a disruptive direction. An aim in this would be to develop reflective practices and reflexivity among those who will educate new generations of (international) entrepreneurs, and among consultants to ventures that are seeking to internationalize. In pursuing this aim, we would seek to help individuals to keep their personal mental constructions of IE scripts open and accessible to new meanings - meanings perceivable in the ongoing sense-making of international entrepreneurial processes, or outcomes.

In discussing one's personal narrative, and the development of personally meaningful behavior, one can be defined, challenged, or empowered by the experiences one has gone through. Hence, we would encourage international entrepreneurs to explore and become aware of the underlying guiding scripts in their thinking, behavior, and even emotional responses to certain situations. The situations might involve, e.g., rapid growth or a new country context, and the responses might involve, e.g., uncertainty or over-rapid rejection of ideas.

Our study suggests that certain beliefs regarding the self, and certain interpretations of social surroundings, may hinder (potential) international entrepreneurs' willingness to take on certain risks, to invite an investor onboard, or to continue with an international business partner. On the other hand, there can be certain deeply-rooted beliefs regarding the self, plus early-developed scripts (such as engagement in cultural interaction) that may anchor one's behavior in something profoundly personal, even if everything else (e.g., the work role and the country context) changes over time. All in all, the above-mentioned scripts may serve as analytical windows to founders, shedding light on their behavior relative to IE.

In our data, retrospection of the past drew autobiographical elements from various challenging, rewarding, and incomplete experiences. These included, for example, a multi-cultural family background and exposure to several languages, traveling experiences as a child, expatriation, and subsequent reorientation in a home country, changing family settings, and other meaningful life events. All such events can feed into one's identity construction in IE. It may be helpful to founderCEOs to go over their IE journeys, in other words, to give them authorship of their own IE narrative. In this way, they may develop a sense of who they are in relation to the IE phenomenon and, in so doing, gain a new understanding of their own behavior.

Acknowledgements The authors acknowledge the insightful comments that Lecturer Teppo Sintonen at the University of Jyväskylä and Professor Ulla Hytti at the University of Turku have provided for this study. The work was generously and kindly supported by the Foundation for Economic Education in Finland and the Finnish Cultural Foundation. 
Funding Information Open access funding provided by LUT University.

Open Access This article is distributed under the terms of the Creative Commons Attribution 4.0 International License (http://creativecommons.org/licenses/by/4.0/), which permits unrestricted use, distribution, and reproduction in any medium, provided you give appropriate credit to the original author(s) and the source, provide a link to the Creative Commons license, and indicate if changes were made.

\section{References}

Acedo FJ, Jones MV (2007) Speed of internationalization and entrepreneurial cognition: insights and a comparison between international new ventures, exporters and domestic firms. J World Bus 42(3):236252. https://doi.org/10.1016/j.jwb.2007.04.012

Autio E (2005) Creative tension: the significance of Ben Oviatt's and Patricia McDougall's article 'toward a theory of international new ventures.'. J Int Bus Stud 36(1):9-19. https://doi.org/10.1057/palgrave. jibs. 8400117

Baker T, Welter F (2018) Contextual entrepreneurship: an interdisciplinary perspective. Foundations and Trends® in Entrepreneurship 14(4):357-426. https://doi.org/10.1561/0300000078

Bandura A (2006) Toward a psychology of human agency. Perspect Psychol Sci 1(2):164-180. https://doi. org/10.1111/j.1745-6916.2006.00011.x

Birch M, Miller T (2000) Inviting intimacy: the interview as therapeutic opportunity. Int J Soc Res Methodol 3(3):189-202. https://doi.org/10.1080/13645570050083689

Boland RJ, Tenkasi RV (1995) Perspective making and perspective taking in communities of knowing. Organ Sci 6(4):350-372. https://doi.org/10.1287/orsc.6.4.350

Brown AD, Stacey P, Nandhakumar J (2008) Making sense of sensemaking narratives. Hum Relat 61(8): 1035-1062. https://doi.org/10.1177/0018726708094858

Bruner J (1995) The autobiographical process. Curr Sociol 43(2):161-177

Butler JE, Doktor R, Lins FA (2010) Linking international entrepreneurship to uncertainty, opportunity discovery, and cognition. J Int Entrep 8(2):121-134. https://doi.org/10.1007/s10843-010-0054-X

Buttriss GJ, Wilkinson IF (2007) Using narrative sequence methods to advance international entrepreneurship theory. J Int Entrep 4(4):157-174. https://doi.org/10.1007/s10843-007-0012-4

Byrne O, Shepherd DA (2015) Different strokes for different folks: entrepreneurial narratives of emotion, cognition, and making sense of business failure. Enterp Theory Pract 39(2):375-405. https://doi. org/10.1111/etap.12046

Carsrud AL, Johnson RW (1989) Entrepreneurship: a social psychological perspective. Entrep Reg Dev 1(1): 21-31. https://doi.org/10.1080/08985628900000003

Coombs JE, Sadrieh F, Annavarjula M (2009) Two decades of international entrepreneurship research: what have we learned-where do we go from here? Int J Entrep 13(1):23-64

Coviello NE (2015) Re-thinking research on born globals. J Int Bus Stud 46(1):17-26. https://doi.org/10.1057 /jibs.2014.59

Coviello NE, Jones MV (2004) Methodological issues in international entrepreneurship research. J Bus Ventur 19(4):485-508. https://doi.org/10.1016/j.jbusvent.2003.06.001

Coviello NE, McDougall PP, Oviatt BM (2011) The emergence, advance and future of international entrepreneurship research — an introduction to the special forum. J Bus Ventur 26(6):625-631. https://doi. org/10.1016/j.jbusvent.2011.07.002

Covin JG, Miller D (2014) International entrepreneurial orientation: conceptual considerations, research themes, measurement issues, and future research directions. Enterp Theory Pract 38(1):11-44. https://doi.org/10.1111/etap.12027

Covin JG, Wales WJ (2012) The measurement of entrepreneurial orientation. Enterp Theory Pract 36(4):677702. https://doi.org/10.1111/j.1540-6520.2010.00432.x

De Clercq DD, Sapienza HJ, Crijns H (2005) The internationalization of small and medium-sized firms. Small Bus Econ 24(4):409-419. https://doi.org/10.1007/s11187-005-5333-x

Dehghanpour Farashah A (2015) The effects of demographic, cognitive and institutional factors on development of entrepreneurial intention: toward a socio-cognitive model of entrepreneurial career. J Int Entrep 13(4):452-476. https://doi.org/10.1007/s10843-015-0144-X 
Delios A (2017) The death and rebirth (?) of international business research. J Manag Stud 54(3):391-397. https://doi.org/10.1111/joms.12222

Ellis PD (2011) Social ties and international entrepreneurship: opportunities and constraints affecting firm internationalization. J Int Bus Stud 42(1):99-127. https://doi.org/10.1057/jibs.2010.20

Evers N, O'Gorman C (2011) Improvised internationalization in new ventures: the role of prior knowledge and networks. Entrep Reg Dev 23(7-8):549-574. https://doi.org/10.1080/08985621003690299

Fauchart E, Gruber M (2011) Darwinians, communitarians, and missionaries: the role of founder identity in entrepreneurship. Acad Manag J 54(5):935-957. https://doi.org/10.5465/amj.2009.0211

Fayolle A, Landstrom H, Gartner WB, Berglund K (2016) The institutionalization of entrepreneurship. Entrep Reg Dev 28(7-8):477-486. https://doi.org/10.1080/08985626.2016.1221227

Fletcher D (2007) 'Toy story': the narrative world of entrepreneurship and the creation of interpretive communities. J Bus Ventur 22(5):649-672. https://doi.org/10.1016/j.jbusvent.2006.10.001

Gartner WB (1988) 'Who is an entrepreneur?' Is the wrong question. American Journal of Small Business 12(4):11-32. https://doi.org/10.1177/104225878801200401

Gartner WB, Bird BJ, Starr JA (1992) Acting as if: differentiating entrepreneurial from organizational behavior. Enterp Theory Pract 16(3):13-32. https://doi.org/10.1177/104225879201600302

Gioia DA, Manz CC (1985) Linking cognition and behavior: a script processing interpretation of vicarious learning. Acad Man Rev 10(3):527-539

Grégoire DA, Corbett AC, McMullen JS (2011) The cognitive perspective in entrepreneurship: an agenda for future research. J Manag Stud 48(6):1443-1477. https://doi.org/10.1111/j.1467-6486.2010.00922.x

Hannibal M (2017) Enacted identities in the university spin-off process-bridging an imaginative gap. J Int Entrep 15(3):239-265. https://doi.org/10.1007/s10843-016-0168-X

Hannibal M, Evers N, Servais P (2016) Opportunity recognition and international new venture creation in university spin-offs - cases from Denmark and Ireland. J Int Entrep 14(3):345-372. https://doi. org/10.1007/s10843-016-0181-0

Hendry PM (2007) The future of narrative. Qual Inq 13(4):487-498. https://doi.org/10.1177 $/ 1077800406297673$

Hiles D, Cermák I (2008) Narrative psychology. In: The Sage handbook of qualitative research in psychology, pp 147-164

Hisrich R, Langan-Fox J, Grant S (2007) Entrepreneurship research and practice: a call to action for psychology. Am Psychol 62(6):575-589. https://doi.org/10.1037/0003-066X.62.6.575

Hollway W (1997) Eliciting narrative through the in-depth interview. Qual Inq 3(1):53-70

Hytti U (2005) New meanings for entrepreneurs: from risk-taking heroes to safe-seeking professionals. J Organ Chang Manag 18(6):594-611. https://doi.org/10.1108/09534810510628521

Joardar A, Wu S (2011) Examining the dual forces of individual entrepreneurial orientation and liability of foreignness on international entrepreneurs. Can J Adm Sci 28(3):328-340. https://doi.org/10.1002 /cjas.203

Johansson AW (2004) Narrating the entrepreneur. Int Small Bus J 22(3):273-293. https://doi.org/10.1177 /0266242604042379

Jones MV, Casulli L (2014) International entrepreneurship: exploring the logic and utility of individual experience through comparative reasoning approaches. Enterp Theory Pract 38(1):45-69. https://doi. org/10.1111/etap.12060

Jones MV, Coviello NE (2005) Internationalisation: conceptualising an entrepreneurial process of behaviour in time. J Int Bus Stud 36(3):284-303. https://doi.org/10.1057/palgrave.jibs.8400138

Jones R, Latham J, Betta M (2008) Narrative construction of the social entrepreneurial identity. Int J Entrep Behav Res 14(5):330-345 https://doi.org/10.1108/13552550810897687

Jones MV, Coviello NE, Tang YK (2011) International entrepreneurship research (1989-2009): a domain ontology and thematic analysis. J Bus Ventur 26(6):632-659. https://doi.org/10.1016/j. jbusvent.2011.04.001

Karp T (2006) The inner entrepreneur: a constructivistic view of entrepreneurial reality construction. J Chang Manag 6(3):291-304. https://doi.org/10.1080/14697010600876864

Keupp MM, Gassmann O (2009) The past and the future of international entrepreneurship: a review and suggestions for developing the field. J Manag 35(3):600-633. https://doi.org/10.1177 /0149206308330558

Kirzner IM (1997) Entrepreneurial discovery and the competitive market process: an Austrian approach. J Econ Lit XXXV

Knight GA, Liesch PW (2016) Internationalization: from incremental to born global. J World Bus 51(1):93102. https://doi.org/10.1016/j.jwb.2015.08.011 
Krueger NF (2007) What lies beneath? The experiential essence of entrepreneurial thinking. Enterp Theory Pract 31(1):123-138

Labov W (2013) The language of life and death: the transformation of experience in oral narrative. Cambridge University Press

Lehto I (2015) International entrepreneurial selling as construction of international opportunities. J Int Entrep 13(3):277-302. https://doi.org/10.1007/s10843-015-0147-7

Leitch CM, Harrison RT (2016) Identity, identity formation and identity work in entrepreneurship: conceptual developments and empirical applications. Entrep Reg Dev 28(3-4):177-190. https://doi.org/10.1080 /08985626.2016.1155740

Lieblich A, Tuval-Mashiach R, Zilber T (1998) Narrative research: reading, analysis, and interpretation, vol 47. Sage

Linstead A, Thomas R (2002) "What Do You Want from Me?" A aoststructuralist feminist reading of middle managers' identities. Cult Organ 8(1):1-20

Lumpkin GT, Dess GG (1996) Clarifying the entrepreneurial orientation construct and linking it to performance. Acad Man Rev 21(1):135. https://doi.org/10.2307/258632

Lumpkin GT, Cogliser CC, Schneider DR (2009) Understanding and measuring autonomy: an entrepreneurial orientation perspective. Enterp Theory Pract 33(1):47-69. https://doi.org/10.1111/j.15406520.2008.00280.x

McAdams DP (2006) The role of narrative in personality psychology today. Narrat Inq 16

McAdams DP (2008) Personal narratives and the life story. In: John O, Robins R, Pervin L (eds) Handbook of personality: theory and research, 3rd edn. Guilford Press, New York, pp 242-262

McAdams DP (2013) The psychological self as actor, agent, and author. Perspect Psychol Sci 8(3):272-295. https://doi.org/10.1177/1745691612464657

McAdams DP, McLean KC (2013) Narrative identity. Curr Dir Psychol Sci 22(3):233-238. https://doi. org/10.1177/0963721413475622

McDougall PP, Shane S, Oviatt BM (1994) Explaining the formation of international new ventures: the limits of theories from international business research. J Bus Ventur 9(6):469-487. https://doi.org/10.1016 /0883-9026(94)90017-5

McDougall-Covin P, Jones MV, Serapio MG (2014) High-potential concepts, phenomena, and theories for the advancement of international entrepreneurship research. Enterp Theory Pract 38(1):1-10. https://doi. org/10.1111/etap.12090

McGaughey SL (2007) Hidden ties in international new venturing: the case of portfolio entrepreneurship. J World Bus 42(3):307-321. https://doi.org/10.1016/j.jwb.2007.04.011

McMullen JS, Dimov D (2013) Time and the entrepreneurial journey: the problems and promise of studying entrepreneurship as a process. J Manag Stud 50(8):1481-1512. https://doi.org/10.1111/joms.12049

Miller D (2011) Miller (1983) revisited: a reflection on EO research and some suggestions for the future. Enterp Theory Pract 35(5):873-894. https://doi.org/10.1111/j.1540-6520.2011.00457.x

Mills CE, Pawson K (2006) Enterprising talk: a case of self construction. Int J Entrep Behav Res 12(6):328344. https://doi.org/10.1108/13552550610710135

Moroz PW, Hindle K (2012) Entrepreneurship as a process: toward harmonizing multiple perspectives. Enterp Theory Pract 36(4):781-818. https://doi.org/10.1111/j.1540-6520.2011.00452.x

Morris MH, Kuratko DF, Schindehutte M, Spivack AJ (2012) Framing the entrepreneurial experience. Enterp Theory Pract 36(1):11-40. https://doi.org/10.1111/j.1540-6520.2011.00471.x

Nielsen SL, Lassen AH (2012) Identity in entrepreneurship effectuation theory: a supplementary framework. Int Entrep Manag J 8(3):373-389. https://doi.org/10.1007/s11365-011-0180-5

Nowiński W, Rialp A (2016) The impact of social networks on perceptions of international opportunities. J Small Bus Manag 54(2):445-461. https://doi.org/10.1111/jsbm.12149

Oviatt BM, McDougall PP (1994) Toward a theory of international new ventures. J Int Bus Stud 25(1):45-64

Oviatt BM, McDougall PP (2005a) The internationalization of entrepreneurship. J Int Bus Stud 36(1):2-8

Oviatt BM, McDougall PP (2005b) Defining international entrepreneurship and modeling the speed of internationalization. Enterp Theory Pract 29(5):537-554. https://doi.org/10.1111/j.15406520.2005.00097.x

Palfrey J, Gasser U (2011) Born digital: understanding the first generation of digital natives. Basic Books, New York

Peiris IK, Akoorie ME, Sinha P (2012) International entrepreneurship: a critical analysis of studies in the past two decades and future directions for research. J Int Entrep 10(4):279-324. https://doi.org/10.1007 /s10843-012-0096-3

Polkinghorne DE (1988) Narrative knowing and the human sciences. Suny Press 
Prashantham S, Kumar K, Bhagavatula S, Sarasvathy SD (2019) Effectuation, network-building and internationalisation speed. Int Small Bus J 37(1):3-21. https://doi.org/10.1177/0266242618796145

Randerson K (2016) Entrepreneurial orientation: do we actually know as much as we think we do? Entrep Reg Dev 28(7-8):580-600. https://doi.org/10.1080/08985626.2016.1221230

Rasmussen ES, Koed Madsen T, Evangelista F (2001) The founding of the Born Global company in Denmark and Australia: sensemaking and networking. Asia Pac J Mark Logist 13(3):75-107. https://doi. org/10.1108/13555850110764793

Rehn A, Brännback M, Carsrud A, Lindahl M (2013) Challenging the myths of entrepreneurship? Entrep Reg Dev 25(7-8):543-551. https://doi.org/10.1080/08985626.2013.818846

Reuber AR, Knight GA, Liesch PW, Zhou L (2018) International entrepreneurship: the pursuit of entrepreneurial opportunities across national borders. J Int Bus Stud 49(4):395-406. https://doi.org/10.1057 /s41267-018-0149-5

Ricoeur P (1991) Narrative identity. Philos Today 35(1):73-81

Riessman CK (1993) Narrative analysis, vol 30. Sage

Rosenthal G (1993) Reconstruction of life stories: principles of selection in generating stories for narrative biographical interviews. The Narrative Study of Lives 1(1):59-91

Sarasvathy SD (2001) Causation and effectuation: toward a theoretical shift from economic inevitability to entrepreneurial contingency. Acad Man Rev 26(2):243-263

Sarasvathy SD, Kumar K, York JG, Bhagavatula S (2014) An effectual approach to international entrepreneurship: overlaps, challenges, and provocative possibilities. Enterp Theory Pract 38(1):71-93. https://doi.org/10.1111/etap.12088

Schumpeter JA (1934) Change and the entrepreneur. In: Essays of J. A. Schumpeter

Selden PD, Fletcher DE (2015) The entrepreneurial journey as an emergent hierarchical system of artifactcreating processes. J Bus Ventur 30(4):603-615. https://doi.org/10.1016/j.jbusvent.2014.09.002

Shane S, Locke EA, Collins CJ (2003) Entrepreneurial motivation. Hum Resour Manag Rev 13(2):257-279. https://doi.org/10.1016/S1053-4822(03)00017-2

Sommer L, Haug M (2011) Intention as a cognitive antecedent to international entrepreneurshipunderstanding the moderating roles of knowledge and experience. Int Entrep Manag J 7(1):111-142. https://doi.org/10.1007/s11365-010-0162-z

Stewart WH, Watson WE, Carland JC, Carland JW (1999) A proclivity for entrepreneurship. J Bus Ventur 14(2):189-214. https://doi.org/10.1016/S0883-9026(97)00070-0

Steyaert C (1997) A qualitative methodology for process studies of entrepreneurship. Int Stud Manag Organ 27(3):13-33. https://doi.org/10.1080/00208825.1997.11656711

Steyaert C (2007) 'Entrepreneuring' as a conceptual attractor? A review of process theories in 20 years of entrepreneurship studies. Entrep Reg Dev 19(6):453-477. https://doi.org/10.1080/08985620701671759

Steyaert C, Katz J (2004) Reclaiming the space of entrepreneurship in society: geographical, discursive and social dimensions. Entrep Reg Dev 16(3):179-196. https://doi.org/10.1080/0898562042000197135

van Burg E, Romme AG (2014) Creating the future together: toward a framework for research synthesis in entrepreneurship. Enterp Theory Pract 38(2):369-397. https://doi.org/10.1111/etap.12092

Watson TJ (2009) Narrative, life story and manager identity: a case study in autobiographical identity work. Hum Relat 62(3):425-452. https://doi.org/10.1177/0018726708101044

Weaver MK, Dickson PH, Gibson B, Turner A (2002) Being uncertain: the relationship between entrepreneurial orientation and environmental uncertainty. Journal of Enterprising Culture 10(2):87-105

Weick KE (1995) Sensemaking in organizations. Sage, Thousand Oaks

Williams CC, Nadin SJ (2013) Beyond the entrepreneur as a heroic figurehead of capitalism: re-representing the lived practices of entrepreneurs. Entrep Reg Dev 25(7-8):552-568. https://doi.org/10.1080 /08985626.2013.814715

Yitshaki R, Kropp F (2016) Entrepreneurial passions and identities in different contexts: a comparison between high-tech and social entrepreneurs. Entrep Reg Dev 28(3-4):206-233. https://doi.org/10.1080 /08985626.2016.1155743

Zahra SA, Randerson K, Fayolle F (2013) Corporate entrepreneurship: where are we? Where can we go from here? M@n@gement 16(4):357-361.https://doi.org/10.3917/mana.164.0357

Publisher's note Springer Nature remains neutral with regard to jurisdictional claims in published maps and institutional affiliations. 